\title{
A Strategy to Form Eutectic Molecular Liquids Based on Noncovalent
}

\section{interactions}

Dongkun $\mathrm{Yu}$ and Tiancheng $\mathrm{Mu}^{*}$

*Corresponding author. Email: tcmu@ruc.edu.cn

Department of Chemistry, Renmin University of China, Beijing 100872, P.R. China.

\begin{tabular}{cc}
\hline SI Table of Contents & $\begin{array}{l}\text { Page } \\
\text { number }\end{array}$ \\
\hline Figure S1 & S2 \\
Figure S2 & S3 \\
Figure S3 & S4 \\
Figure S4 & S6 \\
Figure S5 & S7 \\
Figure S6 & S8 \\
Figure S7 & S10 \\
Figure S8 & $\mathrm{S} 11$ \\
Figure S9 & $\mathrm{S} 12$ \\
Figure S10 & $\mathrm{S} 14$ \\
Figure S11 & $\mathrm{S} 15$ \\
Figure S12 & $\mathrm{S} 16$ \\
Figure S13 & $\mathrm{S} 17$ \\
Figure S14 & $\mathrm{S} 18$ \\
Table S1 & $\mathrm{S} 17$ \\
Table S2 & $\mathrm{S} 18$ \\
Table S3 & $\mathrm{S} 21$ \\
Table S4 & $\mathrm{S} 22$ \\
Table S5 & $\mathrm{S} 23$ \\
Table S6 & $\mathrm{S} 24$ \\
Table S7 & $\mathrm{S} 25$ \\
Table S8 & $\mathrm{S} 26$ \\
DFT calculations & $\mathrm{S} 27$ \\
References & $\mathrm{S} 44$ \\
\hline &
\end{tabular}


a)

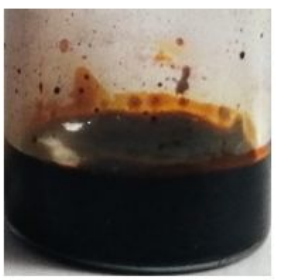

b)

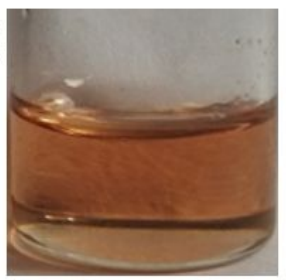

e)

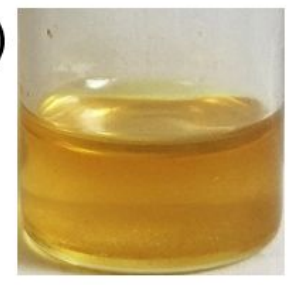

i)
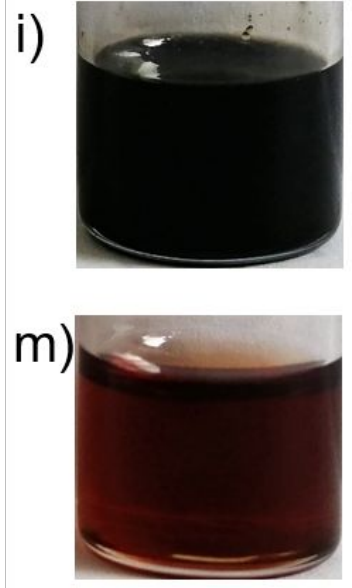

f)

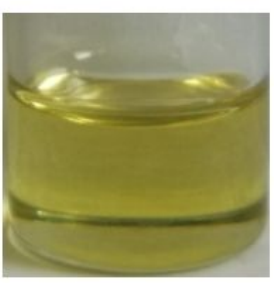

j)

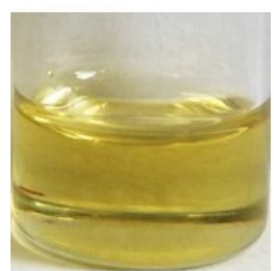

n)

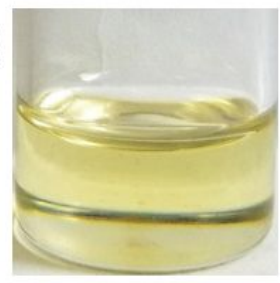

c)

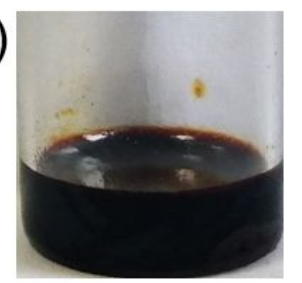

g)

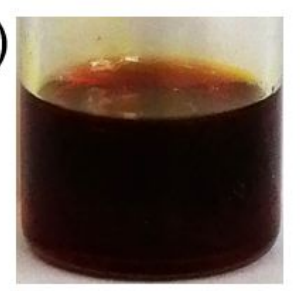

k)

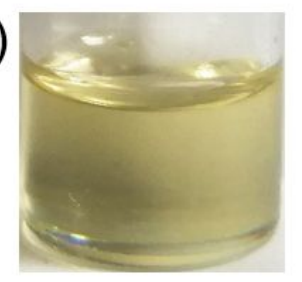

o)

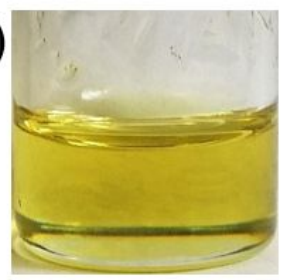

d)

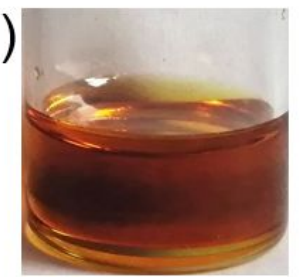

h)

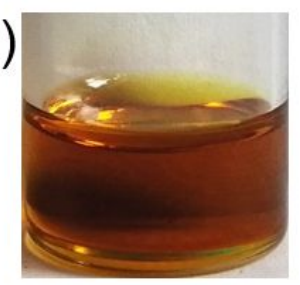

I)

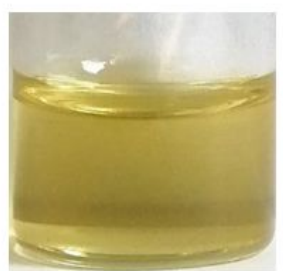

p)

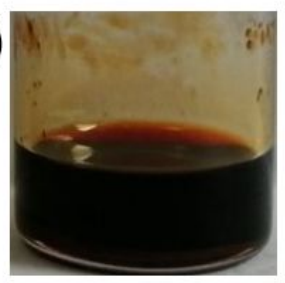

Figure S1. Photographs of 16 EMLs. (a) TB+1, (b) TB+2, (c) TB+3, (d) TB+4, (e) TB+5, (f) $\mathrm{TB}+6$, (g) TB+7, (h) TB+8, (i) TB+9, (j) TB+10, (k) TB+11, (l) TB+12, (m) TB+13, (n) TB+14, (o) $\mathbf{T B}+15$, (p) $\mathbf{T B}+16$. 


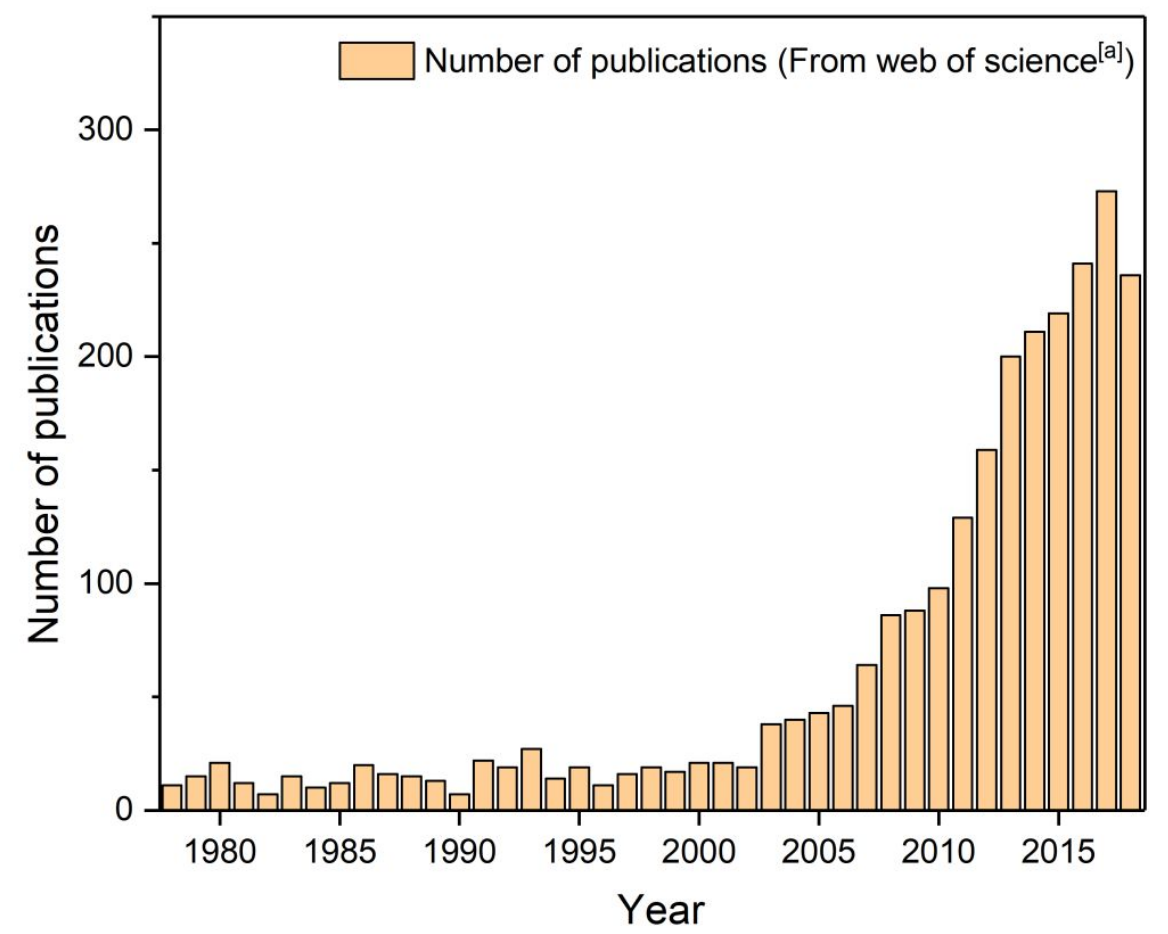

Figure S2. The number of publications about halogen bonds. When searching "halogen bond" as key words of title in Web of Science, the number of publications we got. ${ }^{[a]}$ By the end of 2018. 
a)

c)
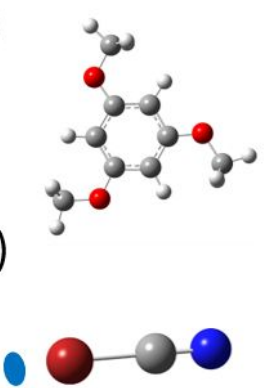

e)

g)

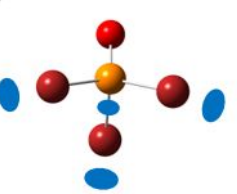

)

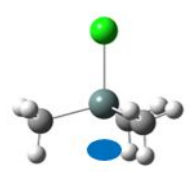

i)

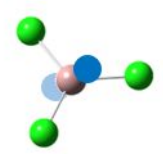

k)

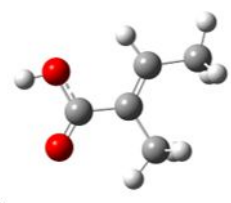

m)

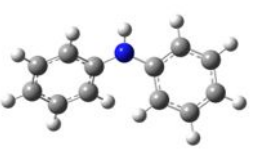

o)

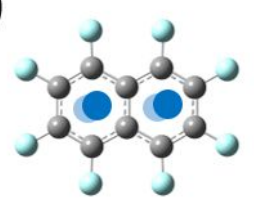

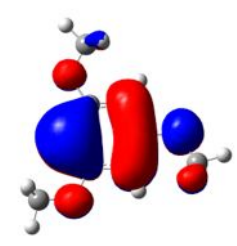
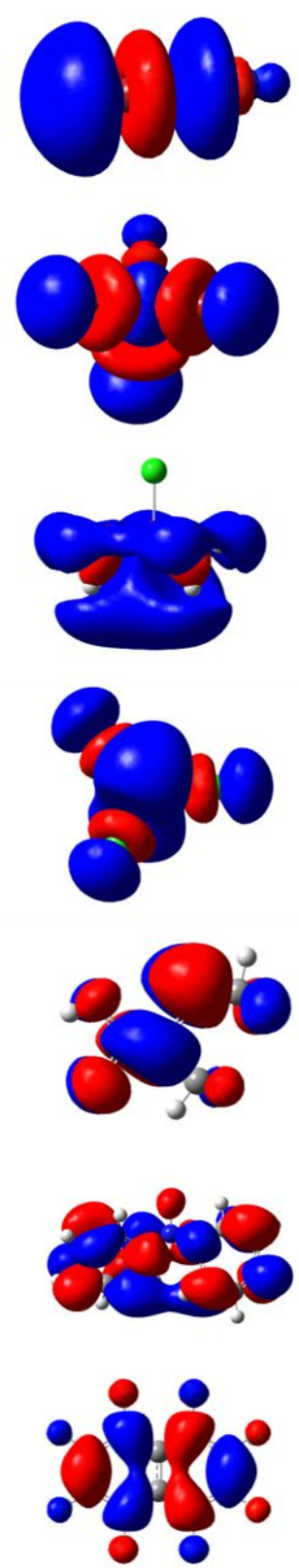

b)
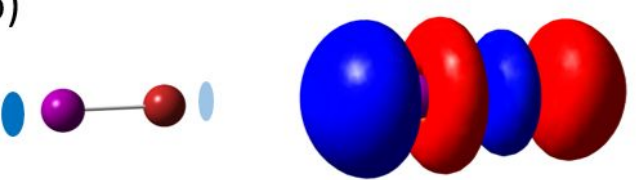

d)

f)

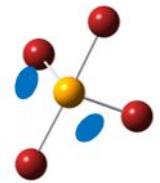

h)

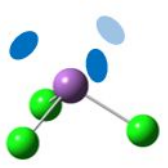

j)

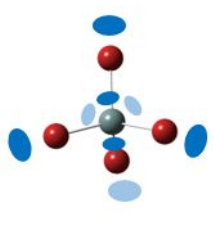

I)
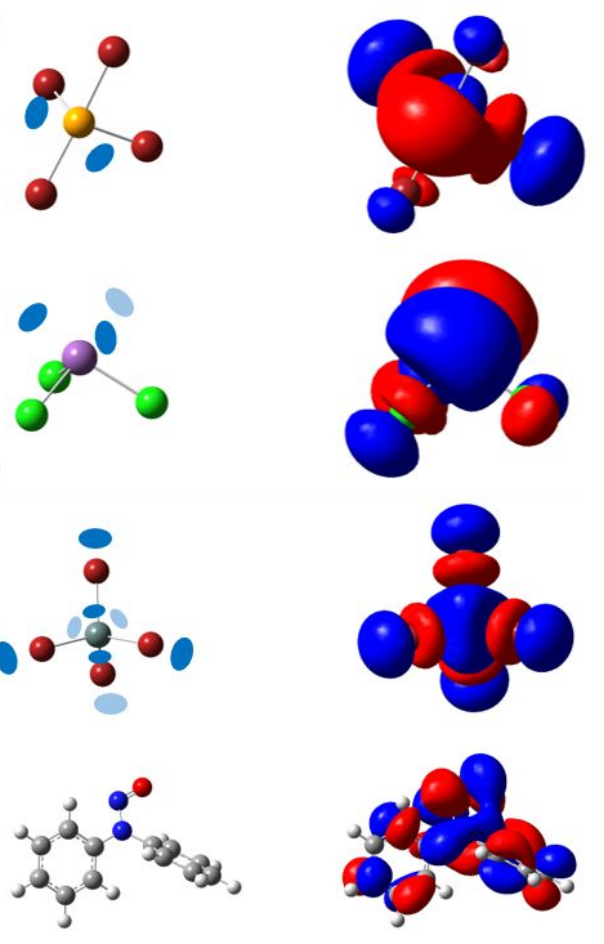

n)
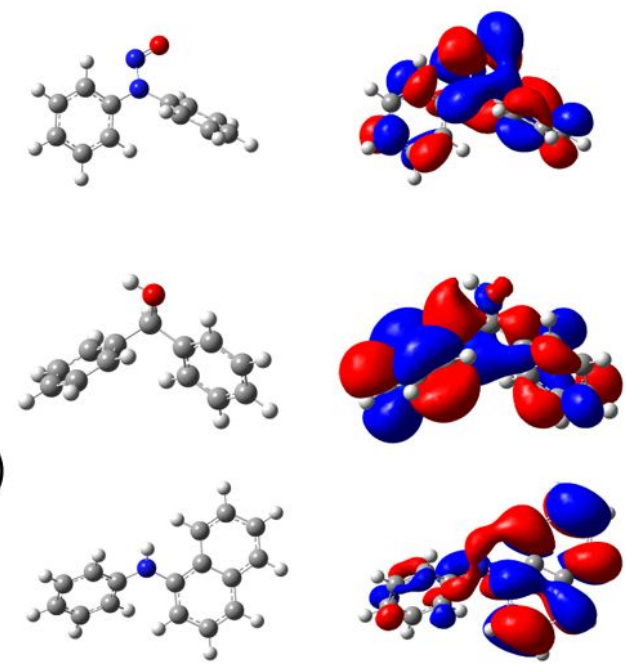

p)
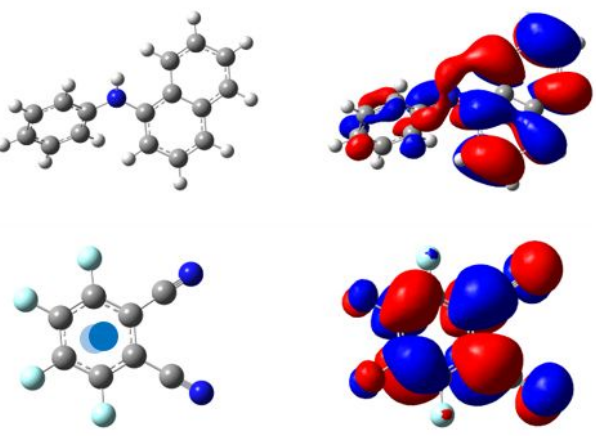

q)

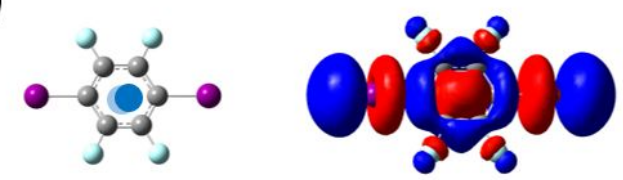

Figure S3. LUMO of TB and HOMO of 1-16. (a) Highest Occupied Molecular Orbital (HOMO) of TB. (b)-(q) Lowest Unoccupied Molecular Orbital (LUMO) of $\mathbf{1}$ to 16. The blue ellipse marks the location of the $\sigma$-hole, $\kappa$-hole and $\pi$-hole. Light blue represents the opposite side. (Red and blue region of orbitals do not represent positive or negative charge, but the phase of orbital.) 
In Figure S3, HOMO of TB and LUMO of 16 electron acceptors were listed. We can find that for electron acceptors, comparing their molecular structures and LUMO, they can be divided into three categories. The first one, the molecules which possess $\sigma$-hole and $\kappa$-hole, such as 1, 2 and $\mathbf{8}$. LUMO of these molecules corresponds well with their holes (where there is any positive hole, there is a distribution of LUMO). Second one, the molecules which possess $\pi$-hole, such as 14, 15 and 16. LUMO of these molecules are quite complex. Third one, the molecules which form hydrogen bond with TB, such as 10,11 and 12. LUMO of these molecules correspond poorly to positive hole. Hydrogen atoms bonded with $\mathrm{N}$ or $\mathrm{O}$ are believed to be a bare proton. These hydrogen atoms are able to form hydrogen bonding interactions, so positive charge position does not correspond to the distribution of LUMO. This exactly verified the correspondence between LUMO and $\sigma$-hole. 


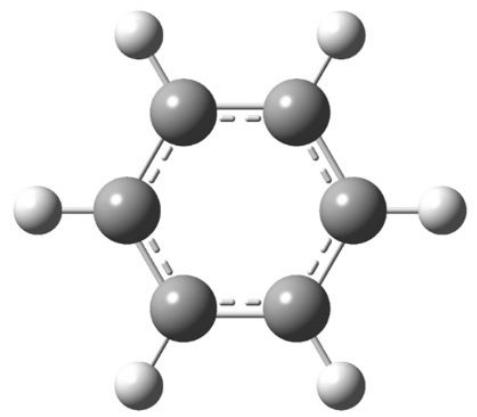

$Q_{\mathrm{zz}}=-5.50$

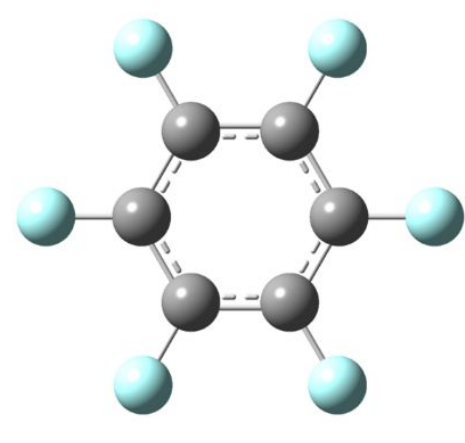

$Q_{z z}=5.74$

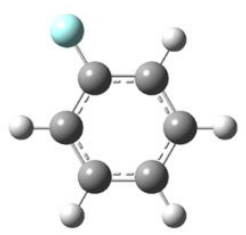

$Q_{\mathrm{zz}}=-1.03$

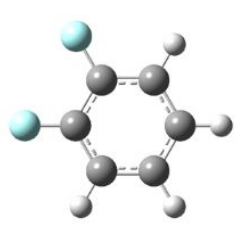

$Q_{z z}=-0.53$

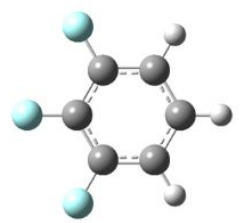

$Q_{z z}=2.54$

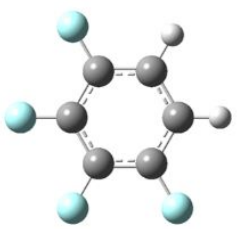

$Q_{z z}=4.39$

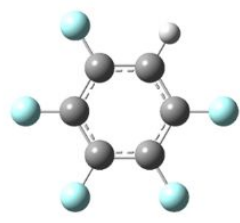

$Q_{z z}=2.26$

Figure S4. Permanent quadrupole moment among $\left(\mathrm{Q}_{\mathrm{zz}}\right)$ of benzene and benzene fluorine derivatives. The unit is Debye-Ang., and he geometries were optimized by M06-2X/def2-pVTZ basis set.

$\mathrm{Q}_{\mathrm{zz}}$ change from -5.5 to 5.75 (Debye-Ang) indicates that from benzene to hexafluorobenzene, $\pi$ hole shows up gradually. Fluorine would attract electrons on the benzene ring when attached to the benzene ring because it is an electron withdrawing group. ${ }^{1}$ The same is it true with other halogen atoms or cyano. So in this work, octafluoronaphthalene, 3,4,5,6-tetrafluorophthalonitrile and 1,4diiodotetrafluorobenzene were chosen to form EMLs with $\mathbf{T B}$. 
a)

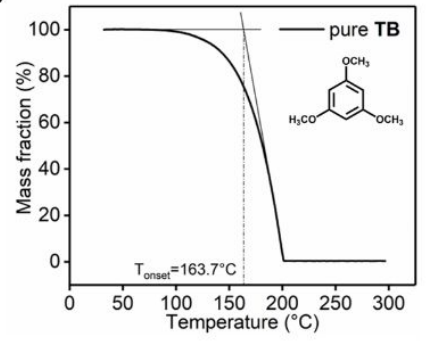

d)

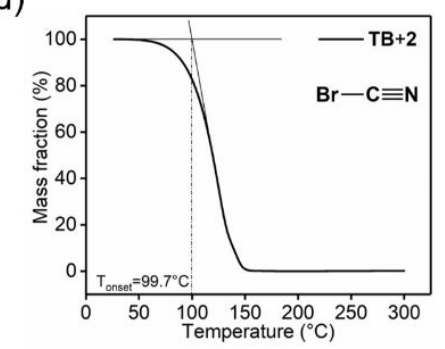

g)

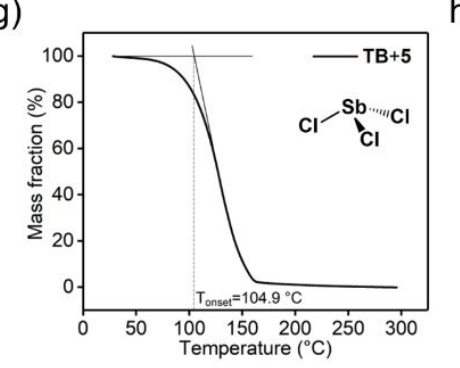

j)

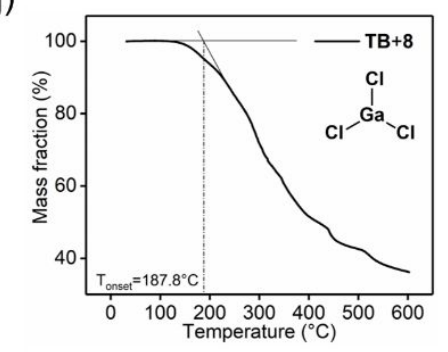

m)

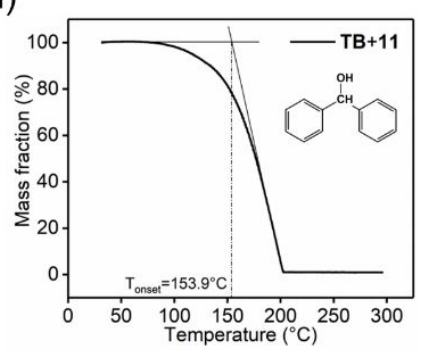

p)

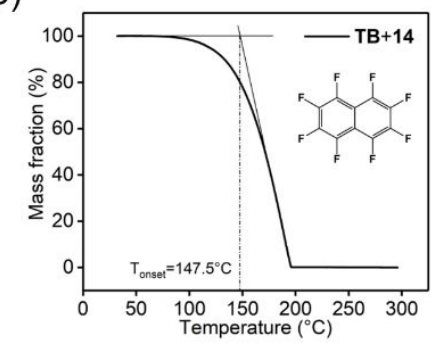

b)

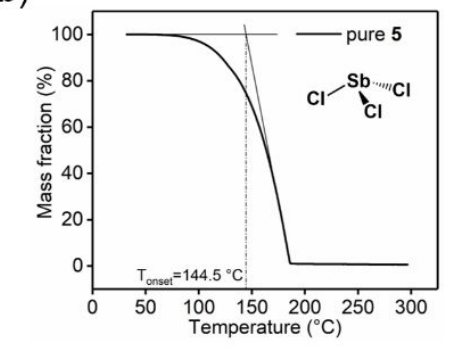

e)

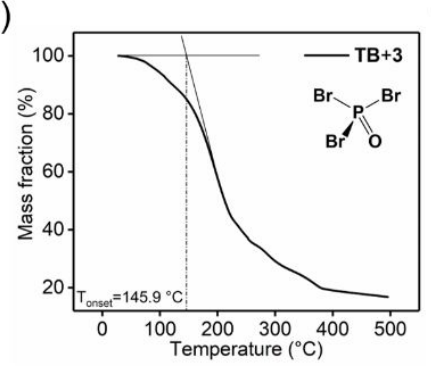

h)

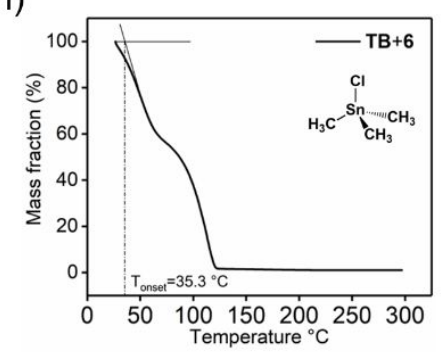

k)

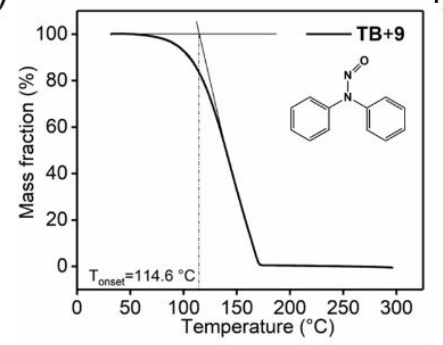

n)

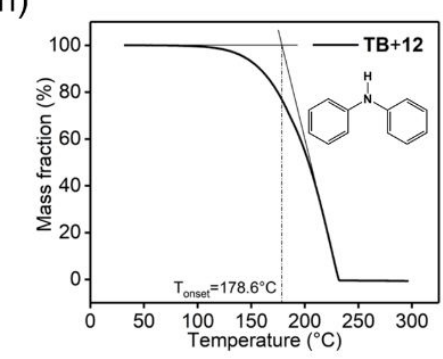

q)

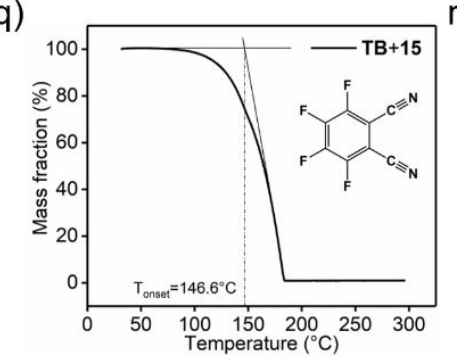

c)

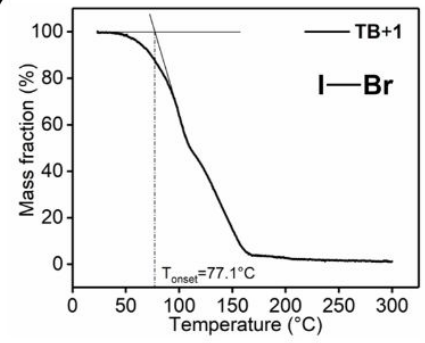

f)

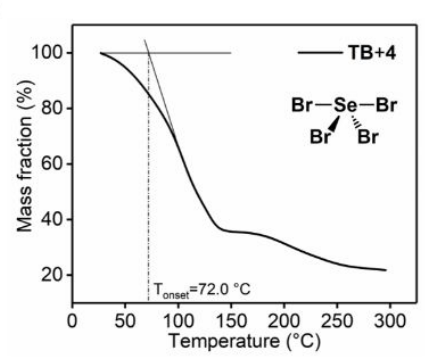

i)

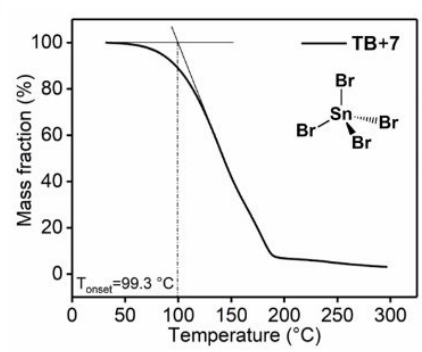

I)

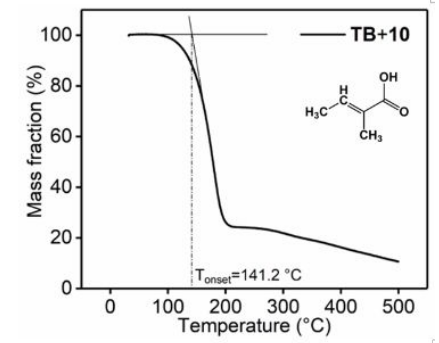

o)

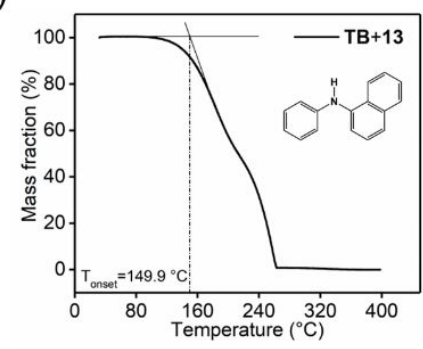

r)

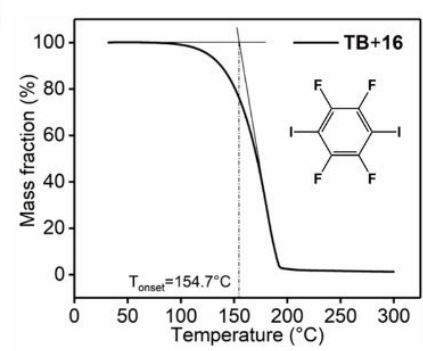

Figure S5. TGA curves of $\mathbf{T B}, \mathbf{5}$ and EMLs $\mathbf{T B}+\mathbf{1}$ to $\mathbf{T B}+\mathbf{1 6}$. 
a)

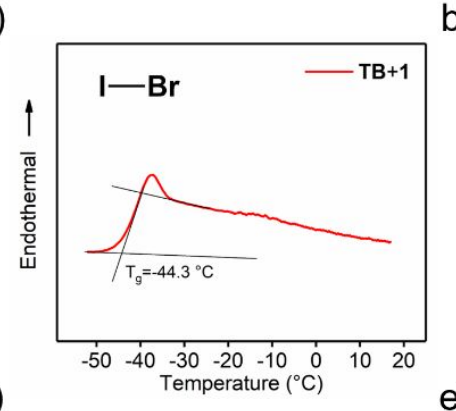

d)

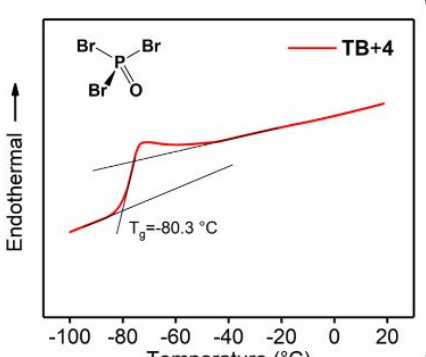

g)

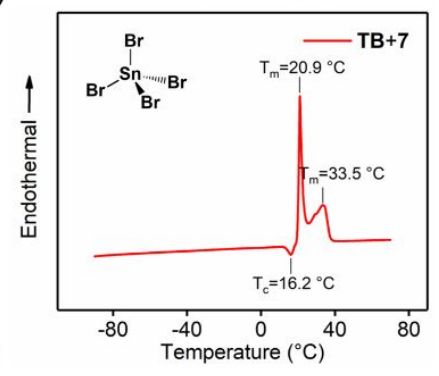

j)

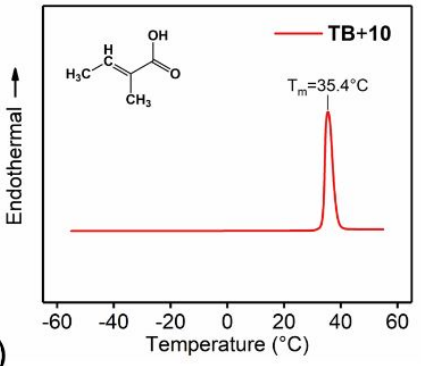

m)

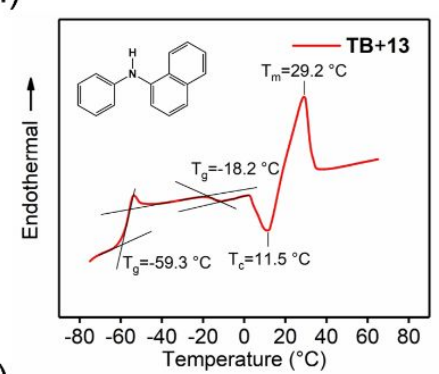

p)

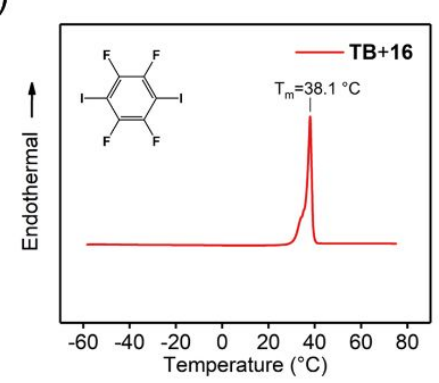

b)

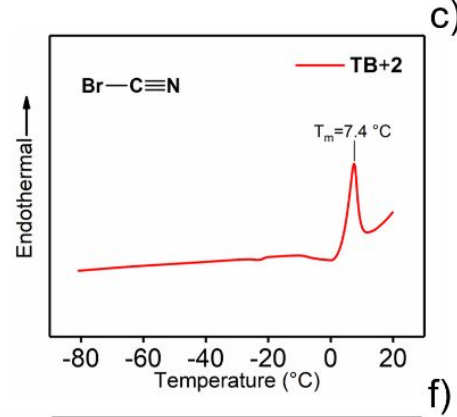

e)

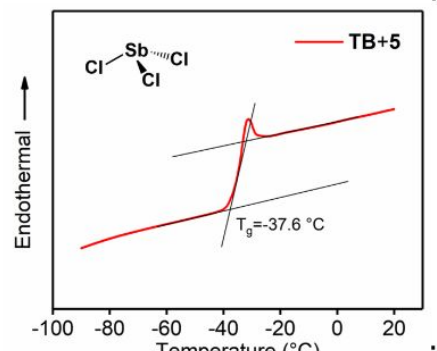

h)

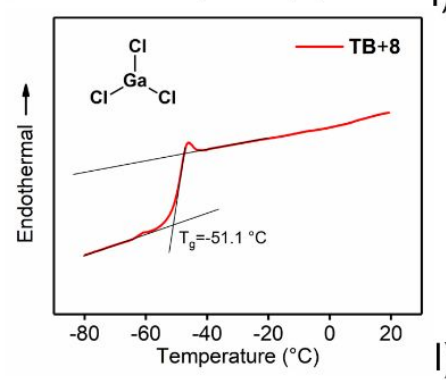

I)

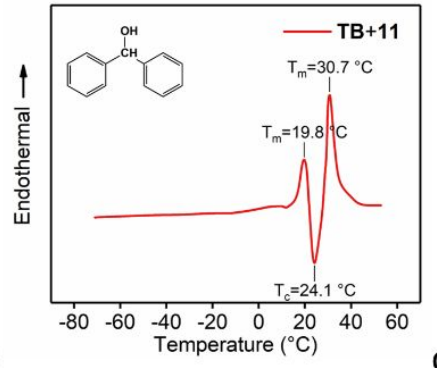

n)

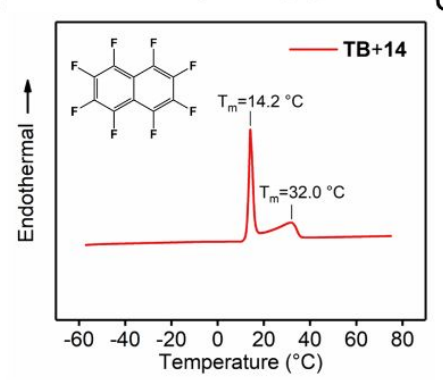

c)
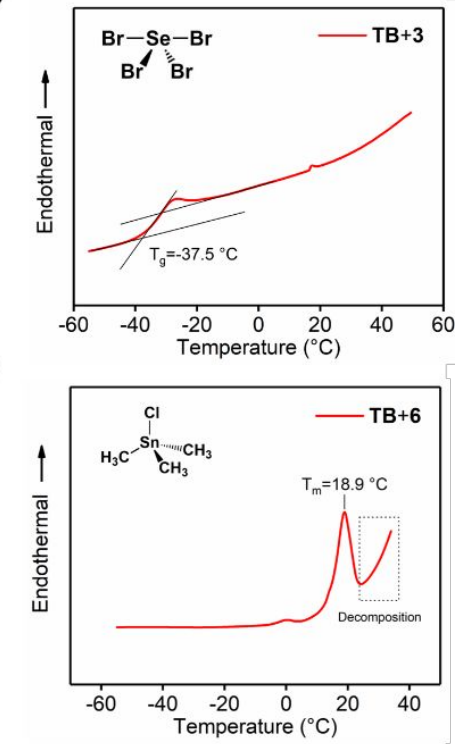

i)
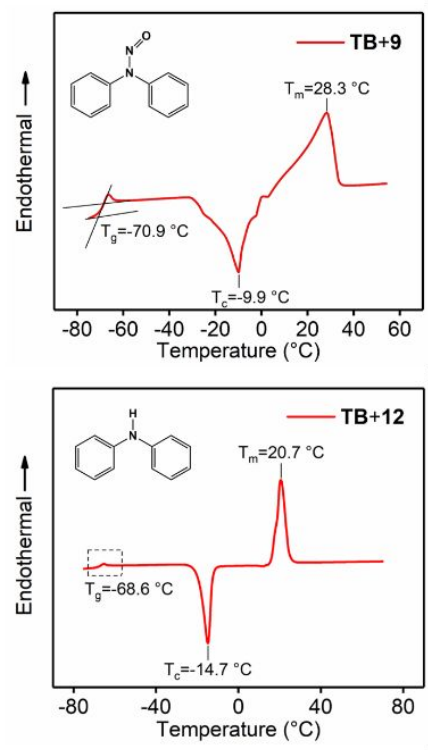

o)

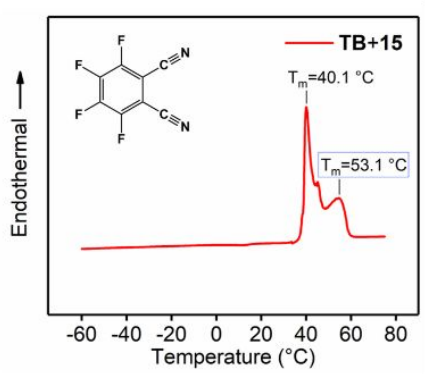

Figure S6. DSC curves of EMLs $\mathbf{T B}+\mathbf{1}$ to $\mathbf{T B}+\mathbf{1 6}$. 
EMLs TB+1, $\mathbf{T B}+\mathbf{3}, \mathbf{T B}+\mathbf{4}, \mathbf{T B}+\mathbf{5}$ and $\mathbf{T B}+\mathbf{8}$ show a $T_{\mathrm{g}}$ (Figure S6a-e, S6h), which indicate the eutectic systems are difficult to crystalize. ${ }^{2}$ EMLs $\mathbf{T B}+\mathbf{7}, \mathbf{T B}+\mathbf{9}, \mathbf{T B}+\mathbf{1 1}, \mathbf{T B}+\mathbf{1 2}$ and $\mathbf{T B}+\mathbf{1 3}$ show both crystallization point and melting point. This is a common phenomenon in the field of co-crystal, especially two components system composed of organic compounds. ${ }^{3}$ While $\mathbf{T B}+\mathbf{2}, \mathbf{T B}+\mathbf{1 0}, \mathbf{T B}+\mathbf{1 4}$, $\mathbf{T B}+15$ and $\mathbf{T B}+\mathbf{1 6}$ show a melting point, which suggest these eutectic systems are easy to crystalize. ${ }^{4}$ It is worth mentioning that there is a peak at $53{ }^{\circ} \mathrm{C}$ in the DSC curve of EML TB+15 which is thought to be the characteristic peak of $\mathbf{T B}$, and the peak at $33.5^{\circ} \mathrm{C}$ in Figure $\mathrm{S} 6 \mathrm{~g}$ is thought to be the chereacteristic peak of 7 . The $\mathrm{T}_{\mathrm{g}}$ ranges from -37.5 to $-80^{\circ} \mathrm{C}$, while $\mathrm{T}_{\mathrm{m}}$ ranges from 18.9 to $40.1{ }^{\circ} \mathrm{C}$. 

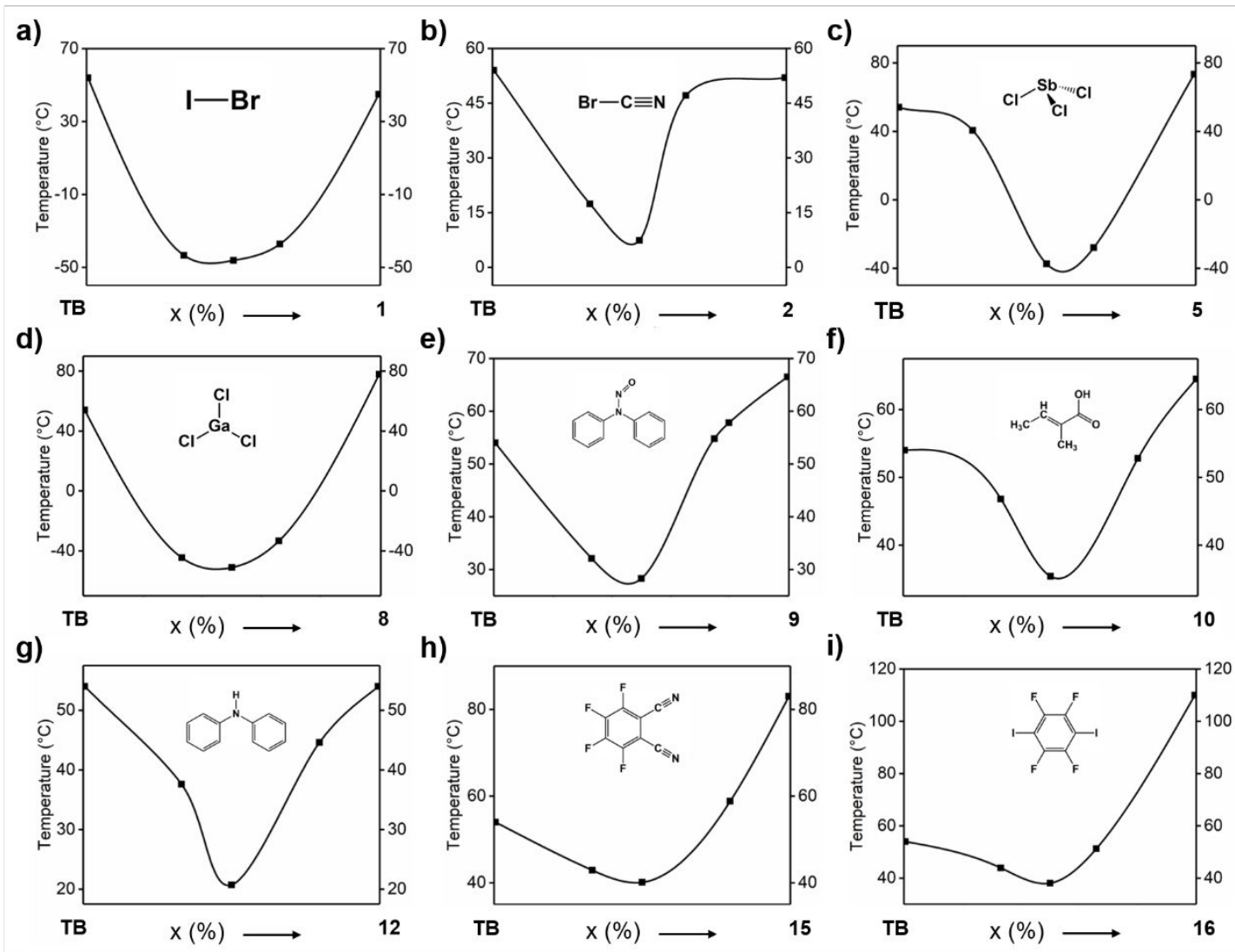

Figure S7. Phase diagrams of 9 EMLs. (a) TB+1, (b) $\mathbf{T B}+\mathbf{2}$, (c) $\mathbf{T B}+\mathbf{5}$, (d) $\mathbf{T B}+\mathbf{8}$, (e) $\mathbf{T B}+\mathbf{9}$, (f) $\mathrm{TB}+10,(\mathrm{~g}) \mathrm{TB}+12$, (h) $\mathrm{TB}+15$, (i) $\mathrm{TB}+16$. 
a)

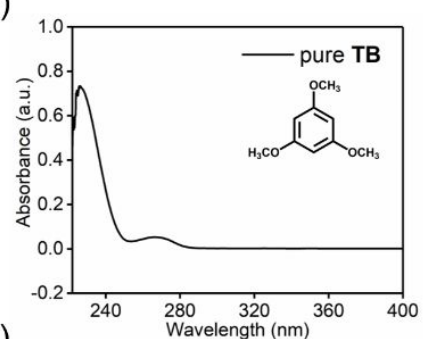

d)

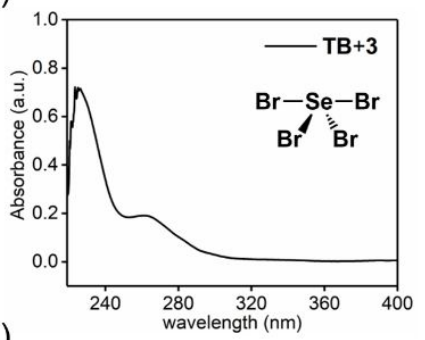

g)

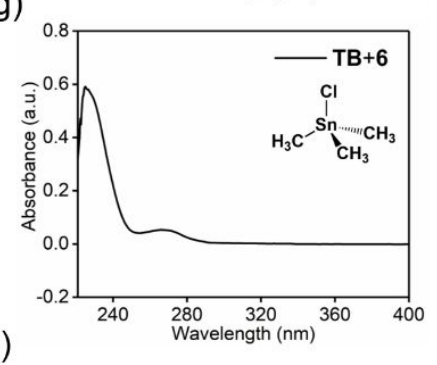

j)

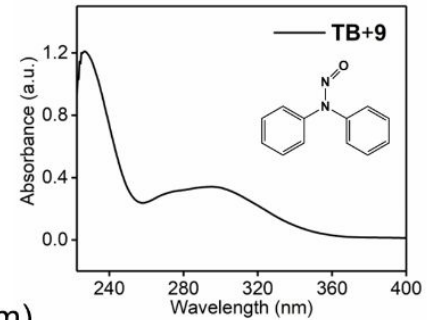

m)

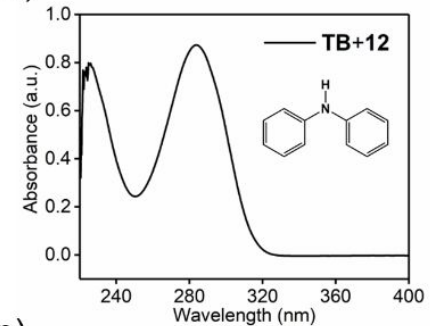

p)

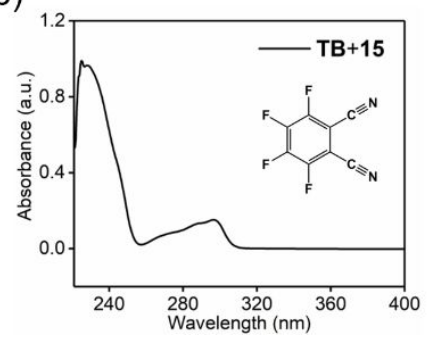

b)

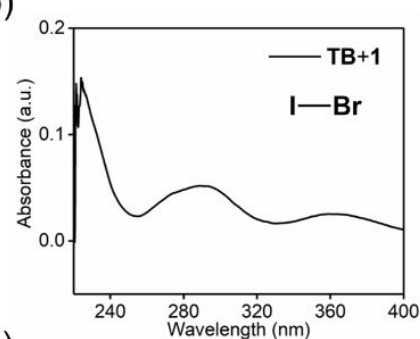

e)

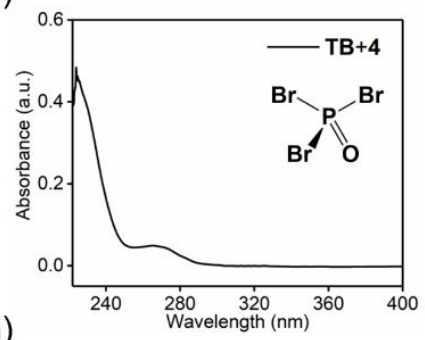

h)

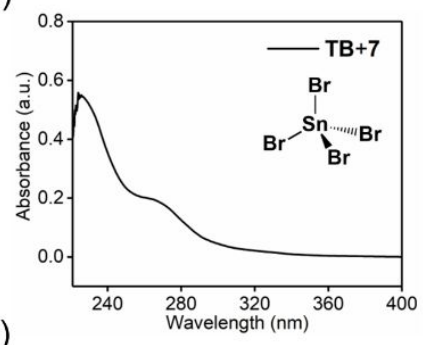

k)

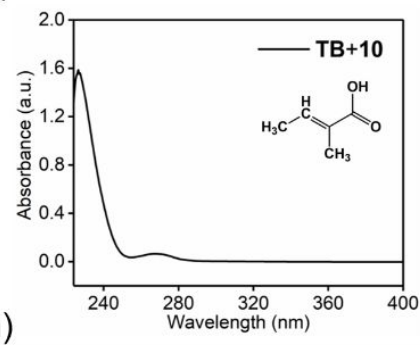

n)

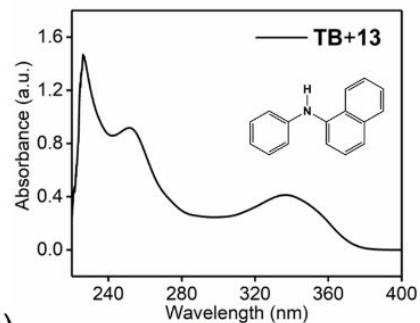

q)

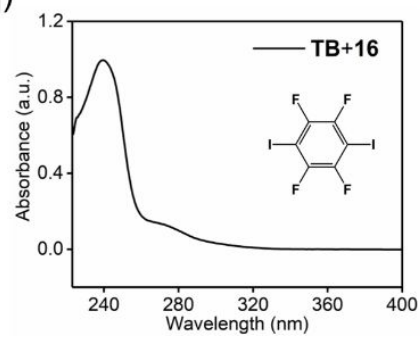

c)

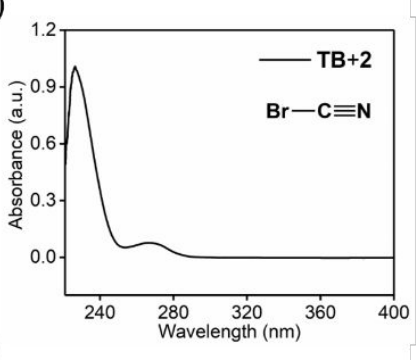

f)

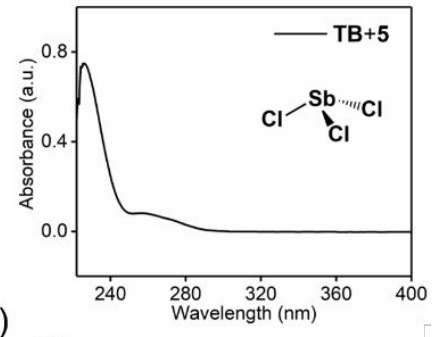

)

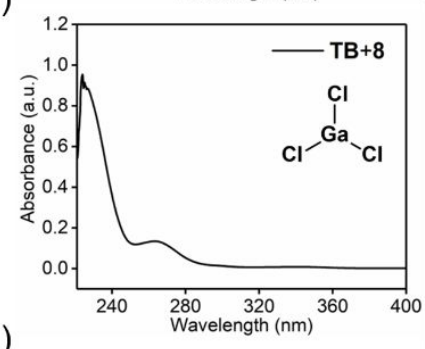

I)

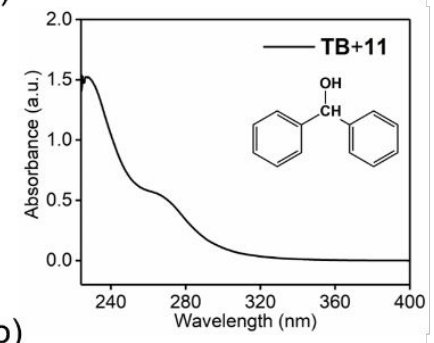

o)

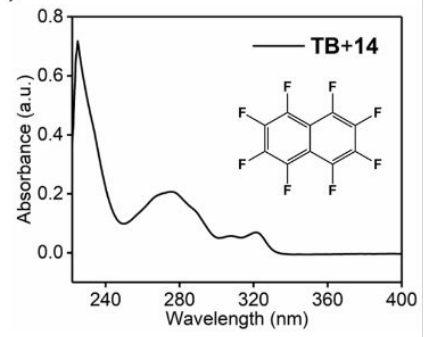

Figure S8. UV spectra of TB and EMLs TB+1 to $\mathbf{T B}+\mathbf{1 6}$. 


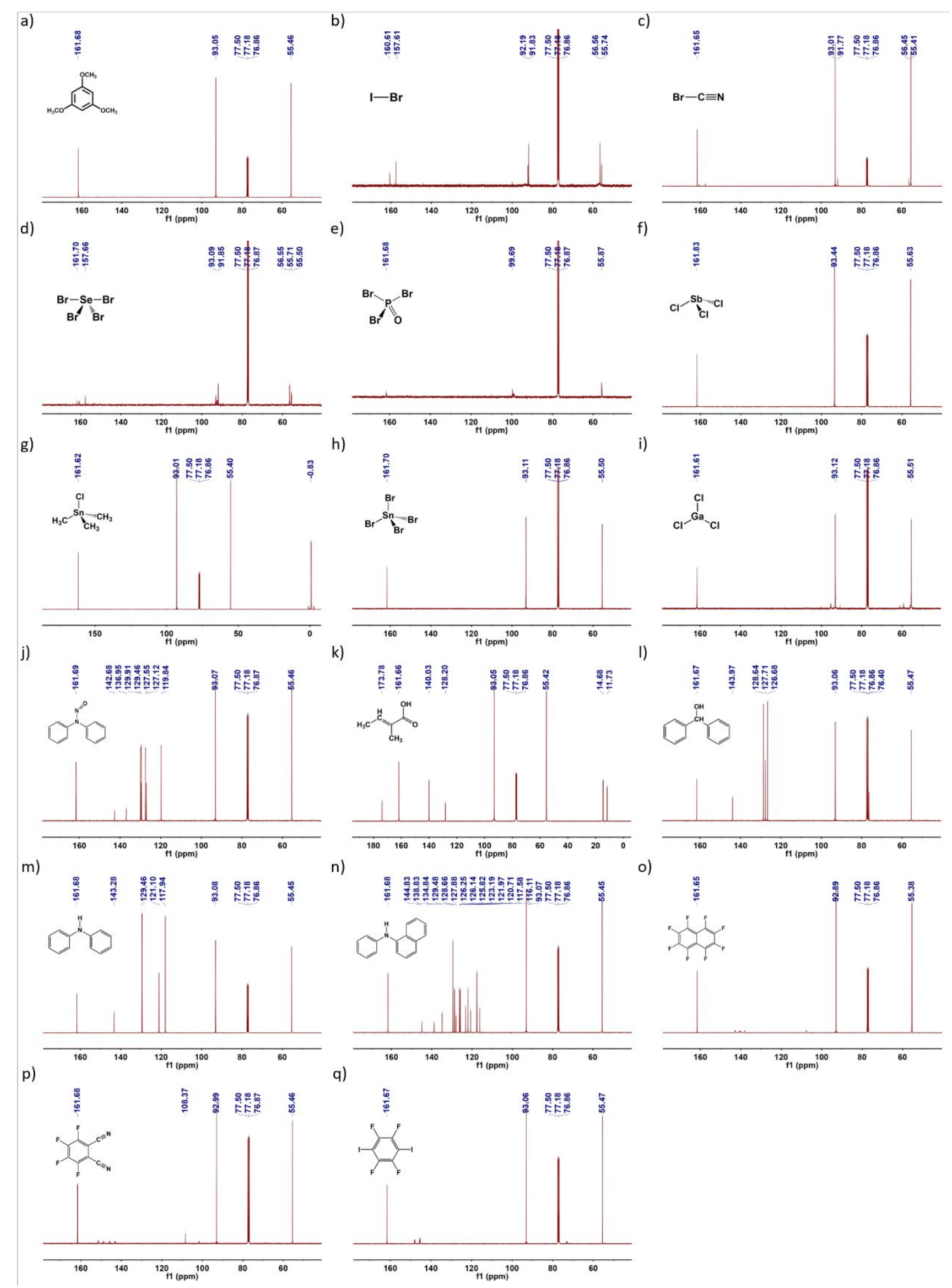

Figure S9. ${ }^{13} \mathrm{C}$ NMR spectra of $\mathbf{T B}$, EMLs $\mathbf{T B}+\mathbf{1}$ to $\mathbf{T B}+\mathbf{1 6}$. (a) and $\mathbf{T B}+\mathbf{1}$ to $\mathbf{T B}+\mathbf{1 6}$ (b) to (q). The structure of the substance contained in the system is in the upper left corner of the spectrum.

In pure $\mathbf{T B}$, the $\delta=55.46 \mathrm{ppm}$ corresponds to methoxy carbon, $\delta=93.05 \mathrm{ppm}$ corresponds to methoxy carbon, $\delta=161.68 \mathrm{ppm}$ corresponds to methoxy carbon. Because $1,3,5$-trimethoxybenzene is very symmetrical, though it possess 9 carbon, there are only 3 kinds of characteristic peaks. 1, 3 and $\mathbf{4}$ are active compounds, so in Figure $\mathrm{S} 8 \mathrm{~b}, 8 \mathrm{~d}$ and $8 \mathrm{e}$, the three characteristic peaks are rather messy. 
This implies that a certain degree of substitution reaction might occur in EMLs. However, 3 characteristic peaks could be recognized easily in most EMLs $(\mathbf{T B}+\mathbf{2}, \mathbf{T B}+\mathbf{5}$ to $\mathbf{T B}+\mathbf{1 6})$. From our point of view, although reactions occured in EMLs $\mathbf{T B}+\mathbf{1}, \mathbf{T B}+\mathbf{3}$ and $\mathbf{T B}+\mathbf{4}$, which is determined by their properties, does not hinder the proposal of EMLs.

TB: ${ }^{13} \mathrm{C}$ NMR $\left(101 \mathrm{MHz}, \mathrm{CDCl}_{3}\right) \delta 161.68,93.05,77.50,77.18,76.86,55.46$.

TB+1: ${ }^{13} \mathrm{C}$ NMR $\left(101 \mathrm{MHz}, \mathrm{CDCl}_{3}\right) \delta 160.61,157.61,92.19,91.83,77.50,77.18,76.86,56.56$, 55.74 .

TB+2: ${ }^{13} \mathrm{C}$ NMR $\left(101 \mathrm{MHz}, \mathrm{CDCl}_{3}\right) \delta 161.65,93.01,91.77,77.50,77.18,76.86,56.45,55.41$.

TB+3: ${ }^{13} \mathrm{C}$ NMR $\left(101 \mathrm{MHz}, \mathrm{CDCl}_{3}\right) \delta 161.83,93.44,77.50,77.18,76.86,55.63$.

TB+4: ${ }^{13} \mathrm{C}$ NMR $\left(101 \mathrm{MHz}, \mathrm{CDCl}_{3}\right) \delta 161.68,99.69,77.50,77.18,76.87,55.87,10.33$.

TB+5: ${ }^{13} \mathrm{C}$ NMR $\left(101 \mathrm{MHz}, \mathrm{CDCl}_{3}\right) \delta 161.70,93.11,77.50,77.18,76.86,55.50$.

TB+6: ${ }^{13} \mathrm{C}$ NMR $\left(101 \mathrm{MHz}, \mathrm{CDCl}_{3}\right) \delta 161.62,93.01,77.50,77.18,76.86,55.40,-0.83$.

TB+7: ${ }^{13} \mathrm{C}$ NMR $\left(101 \mathrm{MHz}, \mathrm{CDCl}_{3}\right) \delta 161.70,157.66,93.09,91.85,77.50,77.18,76.87,56.55$, $55.71,55.50,0.33$.

TB+8: ${ }^{13} \mathrm{C}$ NMR $\left(101 \mathrm{MHz}, \mathrm{CDCl}_{3}\right) \delta 161.61,93.12,77.50,77.18,76.86,55.51$.

TB+9: ${ }^{13} \mathrm{C}$ NMR $\left(101 \mathrm{MHz}, \mathrm{CDCl}_{3}\right) \delta 161.69,142.68,136.95,129.91,129.46,127.55,127.12$, $119.84,93.07,77.50,77.18,76.87,55.46$.

TB+10: ${ }^{13} \mathrm{C}$ NMR $\left(101 \mathrm{MHz}, \mathrm{CDCl}_{3}\right) \delta 173.78,161.66,140.03,128.20,93.05,77.50,77.18,76.86$, $55.42,14.68,11.73$.

TB+11: ${ }^{13} \mathrm{C}$ NMR $\left(101 \mathrm{MHz}, \mathrm{CDCl}_{3}\right) \delta 161.67,143.97,128.64,127.71,126.68,93.06,77.50,77.18$, 76.86, 76.40, 55.47 .

TB+12: ${ }^{13} \mathrm{C}$ NMR $\left(101 \mathrm{MHz}, \mathrm{CDCl}_{3}\right) \delta 161.68,143.28,129.46,121.10,117.94,93.08,77.50,77.18$, 76.86, 55.45.

TB+13: ${ }^{13} \mathrm{C}$ NMR $\left(101 \mathrm{MHz}, \mathrm{CDCl}_{3}\right) \delta 161.68,144.83,138.83,134.84,129.48,128.66,127.88$, 126.25, 126.14, 125.82, 123.19, 121.97, 120.71, 117.58, 116.11, 93.07, 77.50, 77.18, 76.86, 55.45. TB+14: ${ }^{13} \mathrm{C}$ NMR $\left(101 \mathrm{MHz}, \mathrm{CDCl}_{3}\right) \delta 161.67,92.96,77.50,77.18,76.86,55.42$.

TB+15: ${ }^{13} \mathrm{C}$ NMR $\left(101 \mathrm{MHz}, \mathrm{CDCl}_{3}\right) \delta 161.68,108.37,92.99,77.50,77.18,76.87,55.46$.

TB+16: ${ }^{13} \mathrm{C}$ NMR $\left(101 \mathrm{MHz}, \mathrm{CDCl}_{3}\right) \delta 161.67,93.06,77.50,77.18,76.86,55.47$. 
a)

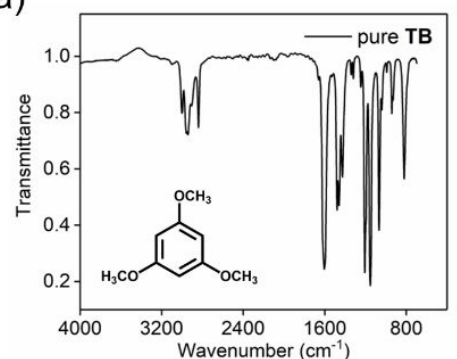

d)

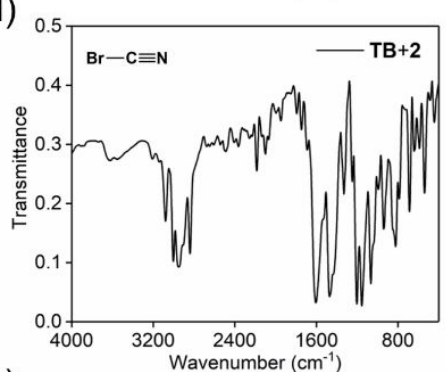

g)

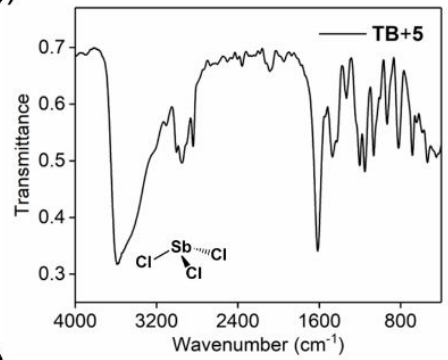

j)

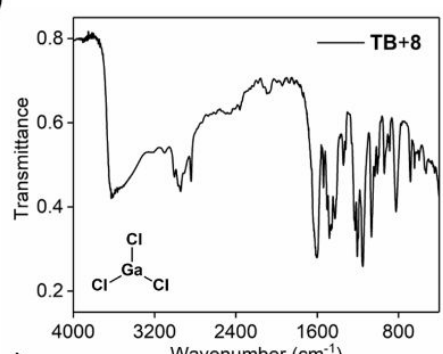

m)
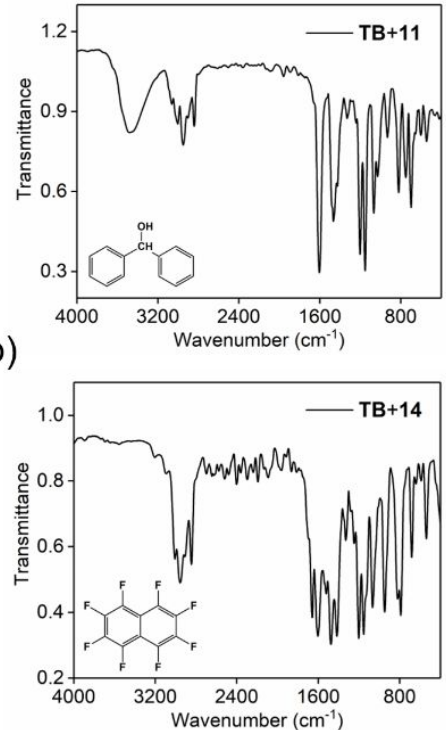

b)

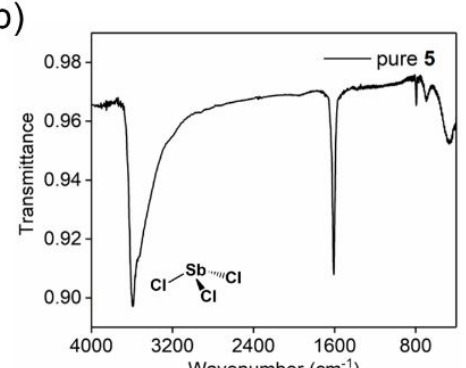

e)

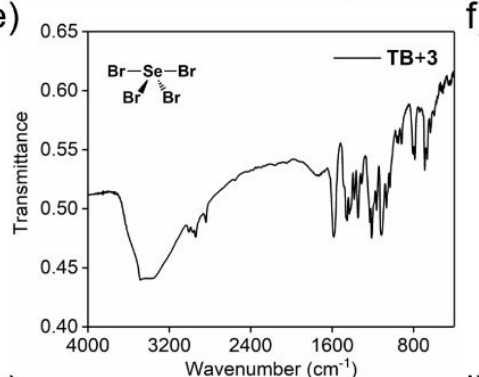

h)

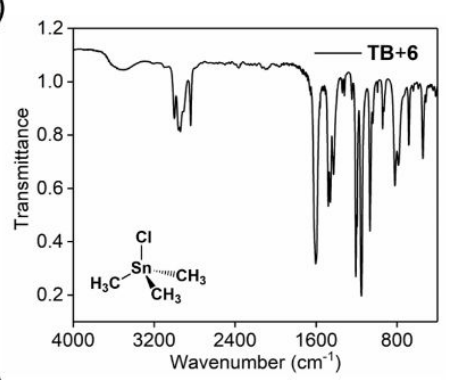

k)

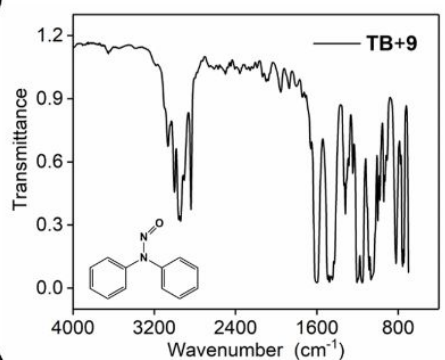

n)

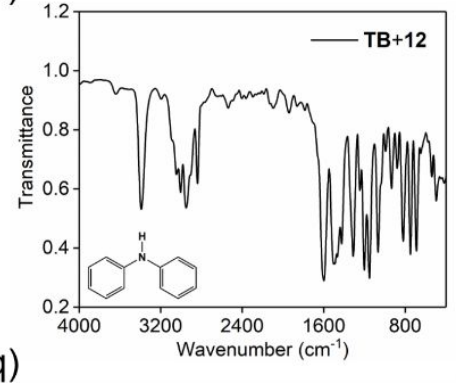

q)

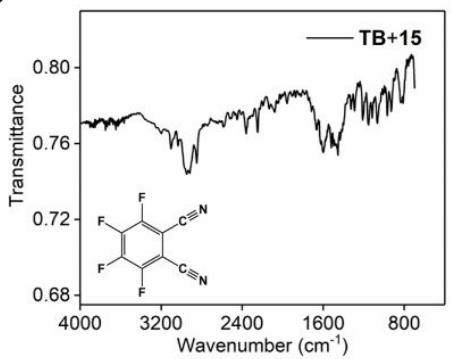

c)

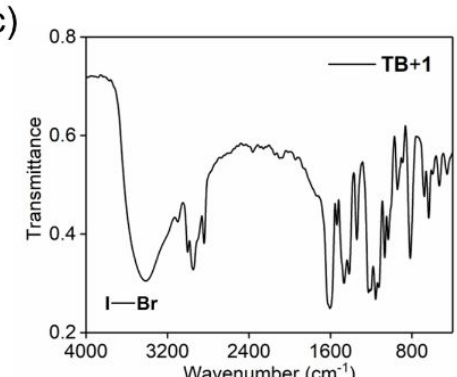

f)

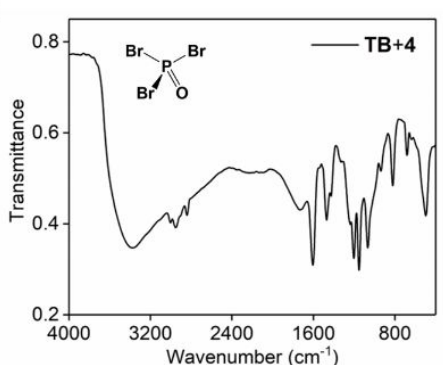

i)

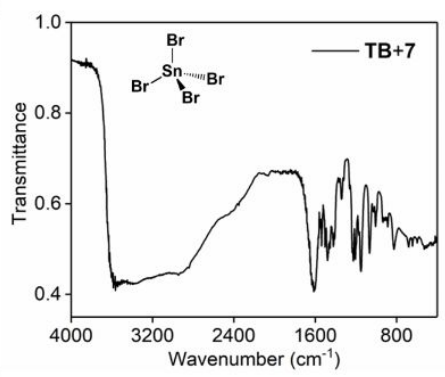

I)

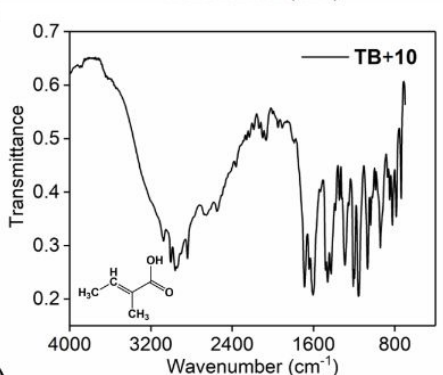

o)
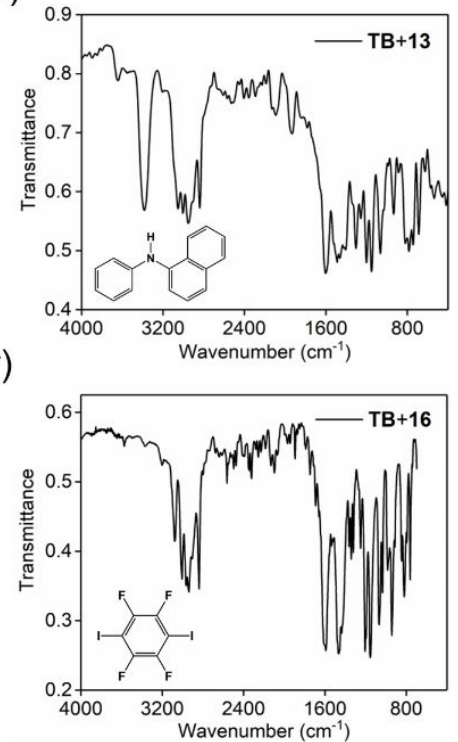

Figure S10. FT-IR spectra of pure $\mathbf{T B}, \mathbf{5}$ and EMLs $\mathbf{T B}+\mathbf{1}$ to $\mathbf{T B}+\mathbf{1 6}$. 


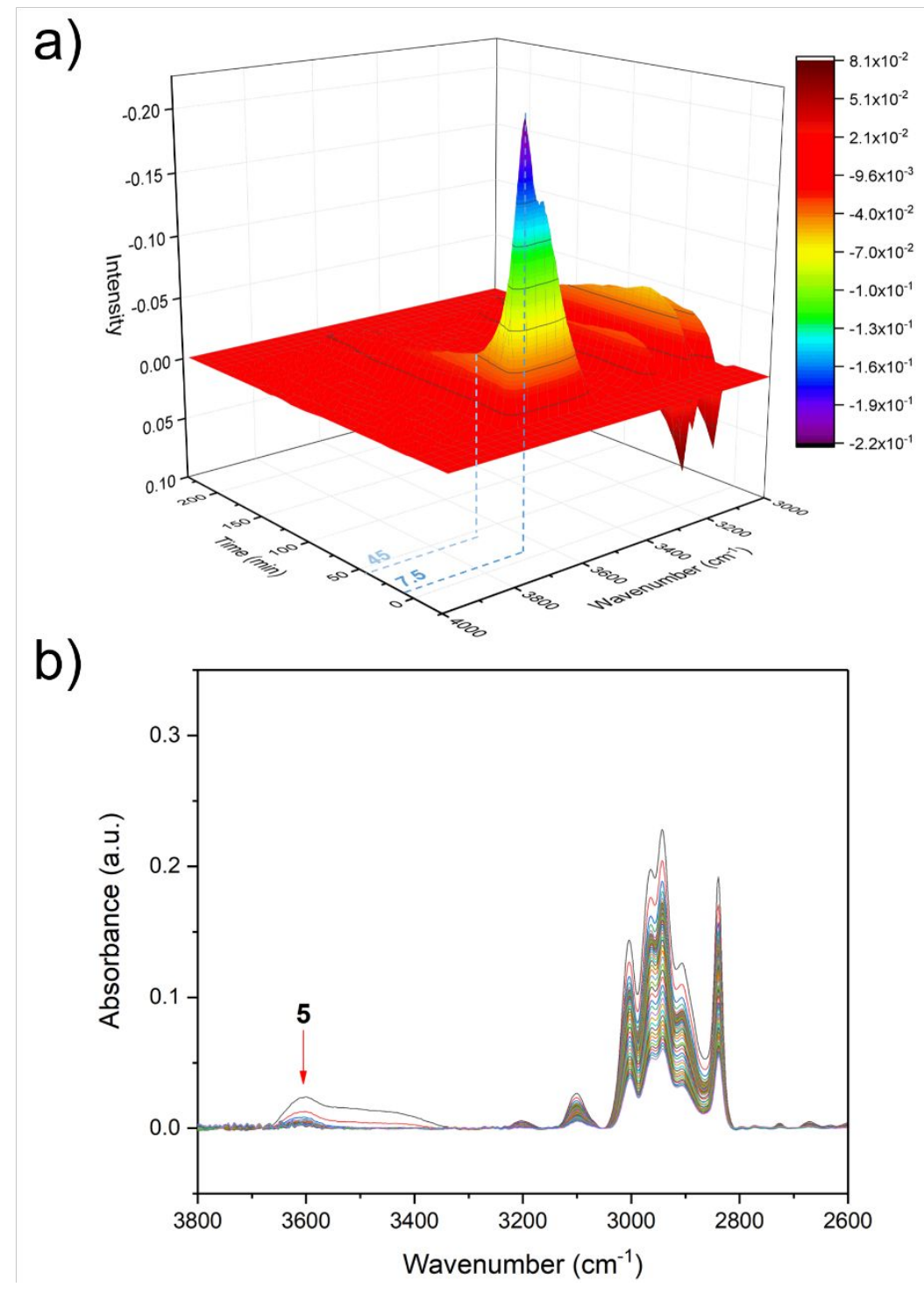

Figure S11. Dynamic IR spectra of EML TB+5. (a) Stereoscopic synchronous perturbationcorrelation moving-window two-dimensional correlation spectroscopy for $\mathbf{T B}+\mathbf{5}$ (mole ratio 1:3). (b) Dynamic IR of $\mathbf{T B}+\mathbf{5}$ (mole ratio 1:1). EML TB+5 evaporates under $1 \mathrm{~atm}$. From up to down correspond to the time from 0 to 210 min with an interval of 6 min.

Comparing to EML $\mathbf{T B}+\mathbf{5}$ (1:3), the evaporation mode of low mole ratio sample (1:1) is relatively simple (Figure S10b). All peaks were decreased, corresponding to TB and $\mathbf{5}$ evaporated at the same time. Moreover, the characteristic peak of $\mathbf{5}$ decreased so quick that it couldn't be recognized during the last 200 minutes. 
a)

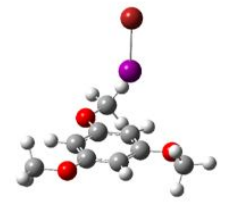

$E_{\text {int }}=-8.31 \mathrm{kcal} / \mathrm{mol}$

f)

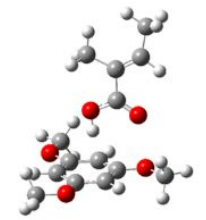

$\mathrm{E}_{\mathrm{int}}=-7.16 \mathrm{kcal} / \mathrm{mol}$

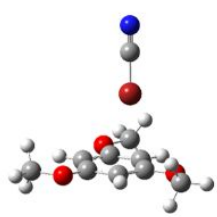

$E_{\text {int }}=-5.00 \mathrm{kcal} / \mathrm{mo}$

g)

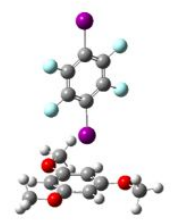

$\mathrm{E}_{\mathrm{int}}=-5.21 \mathrm{kcal} / \mathrm{mo}$

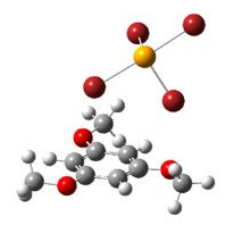

$E_{\text {int }}=-5.13 \mathrm{kcal} / \mathrm{mol}$

h)

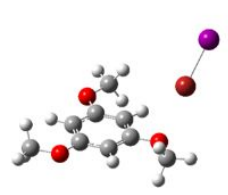

$E_{\text {int }}=-3.62 \mathrm{kcal} / \mathrm{mol}$ d)

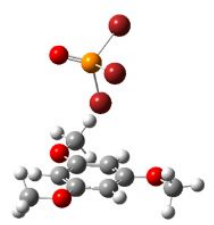

$E_{\text {int }}=-3.92 \mathrm{kcal} / \mathrm{mol}$

i)

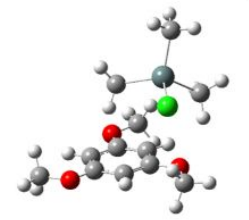

$E_{\text {int }}=-6.92 \mathrm{kcal} / \mathrm{mol}$ e)

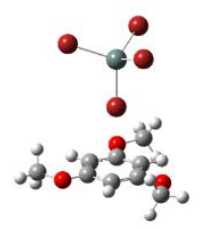

$E_{\text {int }}=-2.91 \mathrm{kcal} / \mathrm{mol}$

j)

Figure S12. Some inferior noncovalent interactions between TB and other molecules.

In liquid state, the interaction form of two molecules is hard to predicted. So some other types of interaction have been studied by giving the interaction energy. 
Table S1. Internal interactions of ILs, DESs and EMLs. Blue represents negative charge, while red represents positive charge. The dark color and sharp shapes represent ions, while the light color and gentle shapes represent molecules. Different kinds of molecules are represented by different geometric shapes. That is, in ILs, the main interaction is the coulomb force. In DESs, the main interactions are coulomb force and noncovalent interaction. In EMLs, the main interaction is noncovalent interactions.

\begin{tabular}{cccc}
\hline & ILs & DESs & EMLs \\
\hline Composition & cation+anion & cation+anion+molecule & moleculeA+moleculeB \\
Main interactions & coulomb force & coulomb force \& hydrogen bonding interactions & noncovalent interactions \\
Model & & &
\end{tabular}


Table S2. Abbreviation or number of substrates in this work. Some selected physical characteristics of $\mathbf{T B}$ and $\mathbf{1}$ to $16^{[\mathrm{a}]}$

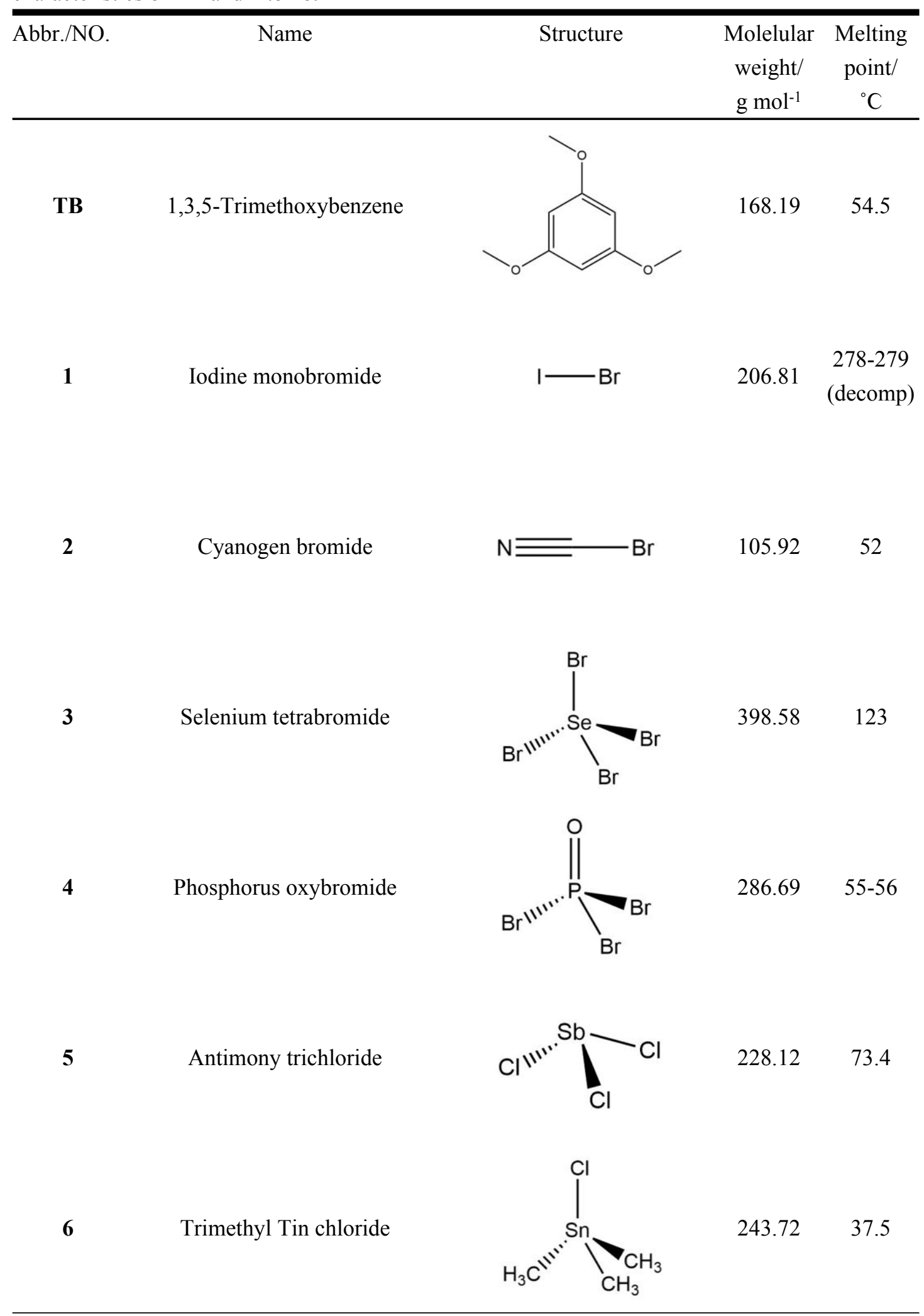




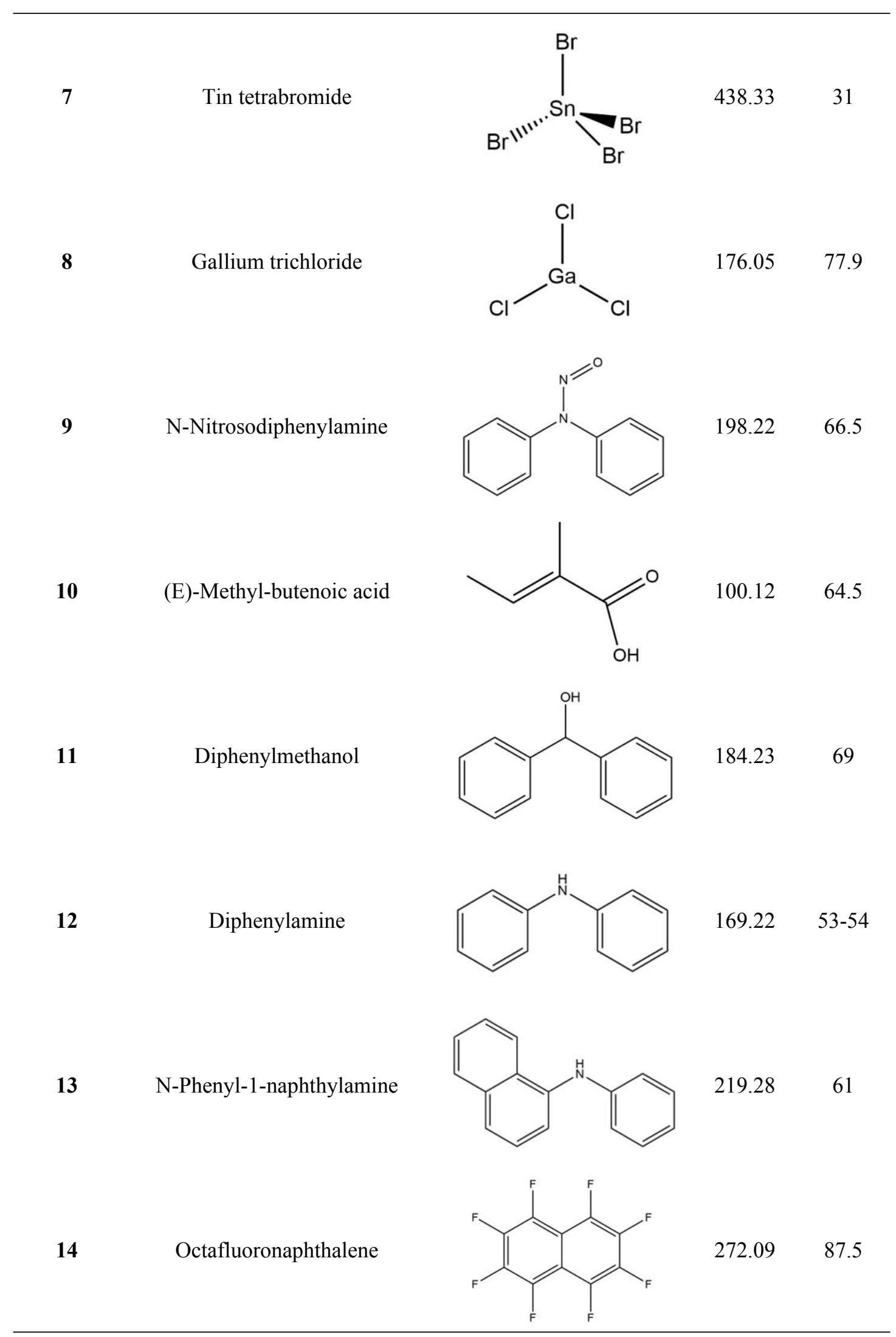




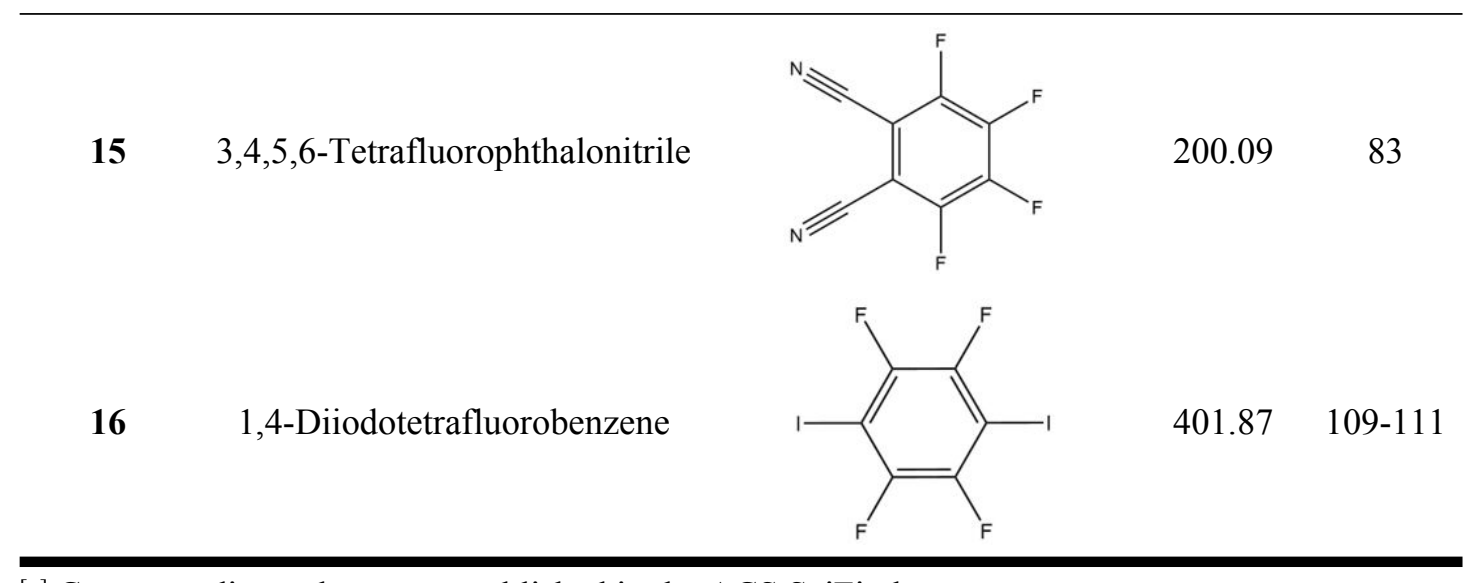

[a] Corresponding values were published in the ACS SciFinder.

All of these substances are solid at room temperature. If TB is mixed with anyone of them, the eutectic phenomenon will take place. They will initially infiltrate each other, and some of them are able to become a homogeneous phase at room temperature. But without agitation and heating, the progress may be lengthy and incompleted. 
Table S3. The onset decomposition temperatures $\left(T_{\text {onset }}\right)$ of pure 5, TB and EMLs $\mathbf{T B}+\mathbf{1}$ to TB+16.

\begin{tabular}{cc}
\hline $\begin{array}{c}\text { Substrate/System } \\
\text { pure } \mathbf{5}\end{array}$ & $\begin{array}{c}T_{\text {onset }} \\
\left({ }^{\circ} \mathrm{C}\right)\end{array}$ \\
$\mathbf{T B}$ & 144.5 \\
$\mathbf{T B}+\mathbf{1}$ & 163.7 \\
$\mathbf{T B}+\mathbf{2}$ & 77.1 \\
$\mathbf{T B}+\mathbf{3}$ & 99.7 \\
$\mathbf{T B}+\mathbf{4}$ & 145.9 \\
$\mathbf{T B}+\mathbf{5}$ & 72.0 \\
$\mathbf{T B}+\mathbf{6}$ & 140.6 \\
$\mathbf{T B}+\mathbf{7}$ & 35.3 \\
$\mathbf{T B}+\mathbf{8}$ & 99.3 \\
$\mathbf{T B}+\mathbf{9}$ & 187.8 \\
$\mathbf{T B}+\mathbf{1 0}$ & 114.6 \\
$\mathbf{T B}+\mathbf{1 1}$ & 141.2 \\
$\mathbf{T B}+\mathbf{1 2}$ & 153.9 \\
$\mathbf{T B}+\mathbf{1 3}$ & 178.6 \\
$\mathbf{T B}+\mathbf{1 4}$ & 149.9 \\
$\mathbf{T B}+\mathbf{1 5}$ & 147.5 \\
$\mathbf{T B}+\mathbf{1 6}$ & 146.6 \\
\hline
\end{tabular}

$T_{\text {onset }}$ was confirmed by intersecting the horizontal baseline and the tangent to the point of maximum decomposition rate. 
Table S4. $T_{\mathrm{g}}$ and $T_{\mathrm{m}}$ of EMLs $\mathbf{T B}+\mathbf{1}$ to $\mathbf{T B}+\mathbf{1 6}$. $^{[\mathrm{a}]}$

\begin{tabular}{|c|c|c|}
\hline System & $\begin{array}{c}T_{g} \\
\left({ }^{\circ} \mathrm{C}\right)\end{array}$ & $\begin{array}{c}T_{m} \\
\left({ }^{\circ} \mathrm{C}\right)\end{array}$ \\
\hline $\mathbf{T B}+1$ & -44.3 & - \\
\hline $\mathbf{T B}+2$ & - & 7.4 \\
\hline $\mathbf{T B}+\mathbf{3}$ & -37.5 & - \\
\hline $\mathbf{T B}+4$ & -80.3 & - \\
\hline $\mathbf{T B}+5$ & -37.6 & - \\
\hline $\mathrm{TB}+6$ & - & 18.9 \\
\hline $\mathbf{T B}+7$ & - & 20.9 \\
\hline $\mathrm{TB}+8$ & -51.1 & - \\
\hline $\mathbf{T B}+9$ & -70.9 & 28.3 \\
\hline $\mathbf{T B}+10$ & - & 35.4 \\
\hline TB +11 & - & 30.7 \\
\hline $\mathrm{TB}+12$ & -68.6 & 20.7 \\
\hline $\mathbf{T B}+13$ & -59.3 & 29.2 \\
\hline TB +14 & - & 30.2 \\
\hline TB +15 & - & 40.1 \\
\hline $\mathrm{TB}+16$ & - & 38.1 \\
\hline
\end{tabular}

[a] All values are obtained from the rising temperature curve.

$T_{\mathrm{g}}$ and $T_{\mathrm{m}}$ were determined by the temperature rising curve. $T_{\mathrm{g}}$ was determined by the intersection of the lower baseline and the tangent to the maximum point of the slope during the glass transition. The peak of the endothermic during the melting process was taken as the $T_{m}$. 
Table S5. UV-vis absorption spectral peaks of $\mathbf{T B}$ along with EMLs $\mathbf{T B}+\mathbf{1}$ to $\mathbf{T B}+\mathbf{1 6}$. The value given is corresponding to the peak absorbance of TB.

\begin{tabular}{|c|c|c|}
\hline Substrate/System & $\begin{array}{c}\text { Peak1 } \\
(\mathrm{nm})\end{array}$ & $\begin{array}{r}\text { Peak2 } \\
(\mathrm{nm})\end{array}$ \\
\hline TB & 226.4 & 266.6 \\
\hline $\mathbf{T B}+\mathbf{1}$ & 224.6 & - \\
\hline $\mathbf{T B}+2$ & 226.6 & 266.6 \\
\hline $\mathbf{T B}+3$ & 226.0 & 261.2 \\
\hline $\mathbf{T B}+4$ & 224.6 & 265.8 \\
\hline $\mathbf{T B}+5$ & 226.2 & 256.4 \\
\hline TB +6 & 225.8 & 266.0 \\
\hline TB +7 & 226.4 & - \\
\hline $\mathbf{T B}+8$ & 225.8 & 263.4 \\
\hline TB +9 & 226.4 & 267.6 \\
\hline $\mathbf{T B}+\mathbf{1 0}$ & 226.6 & - \\
\hline $\mathbf{T B}+11$ & 226.8 & - \\
\hline $\mathbf{T B}+12$ & 225.4 & - \\
\hline $\mathbf{T B}+\mathbf{1 3}$ & 226.6 & - \\
\hline $\mathbf{T B}+14$ & 225.2 & - \\
\hline $\mathbf{T B}+15$ & 225.2 & - \\
\hline $\mathrm{TB}+16$ & 225.5 & - \\
\hline
\end{tabular}


Table S6. NMR shift of TB along with systems $\mathrm{TB}+1$ to $\mathrm{TB}+16$. The chemical shift given is corresponding to the peak of TB.

\begin{tabular}{cccc}
\hline Substrate/System & $\begin{array}{c}\delta 1 \\
(\mathrm{ppm})\end{array}$ & $\begin{array}{c}\delta 2 \\
(\mathrm{ppm})\end{array}$ & $\begin{array}{c}\delta 3 \\
(\mathrm{ppm})\end{array}$ \\
\hline TB & 161.68 & 93.05 & 55.46 \\
$\mathbf{T B}+\mathbf{1}$ & 160.61 & 92.19 & 55.74 \\
$\mathbf{T B}+\mathbf{2}$ & 161.65 & 93.01 & 55.41 \\
$\mathbf{T B}+\mathbf{3}$ & 161.70 & 93.09 & 55.60 \\
$\mathbf{T B}+\mathbf{4}$ & 161.68 & 99.69 & 55.87 \\
$\mathbf{T B}+\mathbf{5}$ & 161.83 & 93.44 & 55.63 \\
$\mathbf{T B}+\mathbf{6}$ & 161.62 & 93.01 & 55.40 \\
$\mathbf{T B}+\mathbf{7}$ & 161.70 & 93.11 & 55.50 \\
$\mathbf{T B}+\mathbf{8}$ & 161.61 & 93.12 & 55.51 \\
$\mathbf{T B}+\mathbf{9}$ & 161.66 & 93.05 & 55.42 \\
$\mathbf{T B}+\mathbf{1 0}$ & 161.69 & 93.07 & 55.42 \\
$\mathbf{T B}+\mathbf{1 1}$ & 161.67 & 93.06 & 55.47 \\
$\mathbf{T B}+\mathbf{1 2}$ & 161.68 & 93.08 & 55.45 \\
$\mathbf{T B}+\mathbf{1 3}$ & 161.66 & 93.07 & 55.45 \\
$\mathbf{T B}+\mathbf{1 4}$ & 161.65 & 92.89 & 55.38 \\
$\mathbf{T B}+\mathbf{1 5}$ & 161.68 & 92.99 & 55.46 \\
$\mathbf{T B}+\mathbf{1 6}$ & 161.67 & 93.06 & 55.47 \\
\hline
\end{tabular}


Table S7. IR spectral peaks of TB along with $\mathbf{T B}+\mathbf{1}$ to $\mathbf{T B}+\mathbf{1 6}$. The value given is corresponding to the peak absorbance of TB.

\begin{tabular}{cccccc}
\hline Substrate/System & $\begin{array}{c}v_{(\mathrm{C}-\mathrm{H})} \\
\mathrm{cm}^{-1}\end{array}$ & $\begin{array}{c}v^{\prime}{ }_{(\mathrm{C}-\mathrm{H})} \\
\mathrm{cm}^{-1}\end{array}$ & $\begin{array}{c}v_{(\mathrm{C}=\mathrm{C})} \\
\mathrm{cm}^{-1}\end{array}$ & $\begin{array}{c}v_{\mathrm{as}(\mathrm{C}-\mathrm{O}-\mathrm{C})} \\
\mathrm{cm}^{-1}\end{array}$ & $\begin{array}{c}v_{\mathrm{s}(\mathrm{C}-\mathrm{O}-\mathrm{C})} \\
\mathrm{cm}^{-1}\end{array}$ \\
\hline $\mathbf{T B}$ & 3001.8 & 2838.5 & 1604.7 & 1206.3 & 1067.5 \\
$\mathbf{T B}+\mathbf{1}$ & 3002.9 & 2839.3 & 1600.1 & 1204.7 & 1066.9 \\
$\mathbf{T B}+\mathbf{2}$ & 3003.1 & 2838.5 & 1602.0 & 1210.0 & 1066.3 \\
$\mathbf{T B}+\mathbf{3}$ & 3008.3 & 2841.5 & 1582.6 & 1211.8 & 1066.7 \\
$\mathbf{T B}+\mathbf{4}$ & 3003.1 & 2840.0 & 1604.1 & 1206.3 & 1067.0 \\
$\mathbf{T B}+\mathbf{5}$ & 3001.8 & 2838.5 & 1600.1 & 1205.4 & 1067.0 \\
$\mathbf{T B}+\mathbf{6}$ & 3000.3 & 2838.5 & 1604.3 & 1206.3 & 1067.0 \\
$\mathbf{T B}+\mathbf{7}$ & - & 2840.0 & 1605.8 & 1205.5 & 1065.8 \\
$\mathbf{T B}+\mathbf{8}$ & 3004.5 & 2840.9 & 1602.1 & 1206.0 & 1065.8 \\
$\mathbf{T B}+\mathbf{9}$ & 3004.6 & 2840.0 & 1603.0 & 1209.2 & 1067.5 \\
$\mathbf{T B}+\mathbf{1 0}$ & 3001.8 & 2838.5 & 1604.2 & 1206.3 & 1065.0 \\
$\mathbf{T B}+\mathbf{1 1}$ & 3001.8 & 2838.5 & 1603.0 & 1204.6 & 1066.7 \\
$\mathbf{T B}+\mathbf{1 2}$ & 3001.8 & 2837.3 & 1601.1 & 1205.7 & 1067.0 \\
$\mathbf{T B}+\mathbf{1 3}$ & 3001.8 & 2837.3 & 1598.4 & 1204.3 & 1067.0 \\
$\mathbf{T B}+\mathbf{1 4}$ & 3008.8 & 2844.3 & 1603.7 & 1207.3 & 1067.0 \\
$\mathbf{T B}+\mathbf{1 5}$ & - & 2848.8 & 1600.0 & 1209.0 & 1065.0 \\
$\mathbf{T B}+\mathbf{1 6}$ & 3007.6 & 2838.5 & 1600.1 & 1204.6 & 1067.0 \\
\hline
\end{tabular}


Table S8. Bond type, interaction energy, bond length and bond angle of each noncovalent interaction.

\begin{tabular}{|c|c|c|c|c|}
\hline System & Bonding type & $\begin{array}{c}\mathrm{E}_{\mathrm{s}} \\
(\mathrm{kcal} / \mathrm{mol})\end{array}$ & $\begin{array}{c}\text { Bond length } \\
(\AA)\end{array}$ & $\begin{array}{c}\text { Bond angle } \\
\left({ }^{\circ}\right)\end{array}$ \\
\hline $\mathbf{T B}+\mathbf{1}$ & $\sigma$-hole bond & -7.03 & 2.81708 & 176.21952 \\
\hline $\mathbf{T B}+2$ & $\sigma$-hole bond & -4.74 & 2.84573 & 175.93756 \\
\hline $\mathbf{T B}+\mathbf{3}$ & $\sigma$-hole bond & -11.76 & 2.79907 & 170.08438 \\
\hline $\mathbf{T B}+4$ & $\sigma$-hole bond & -4.35 & 3.96936 & 175.23867 \\
\hline $\mathbf{T B}+5$ & $\sigma$-hole bond & -9.49 & 2.93029 & 175.16433 \\
\hline $\mathbf{T B}+5$ & $\mu$-hole bond & -3.75 & 4.10816 & - \\
\hline $\mathrm{TB}+6$ & $\sigma$-hole bond & -7.33 & 3.06799 & 171.61340 \\
\hline $\mathbf{T B}+7$ & $\sigma$-hole bond & -5.21 & 3.15271 & 174.80138 \\
\hline $\mathbf{T B}+8$ & $\kappa$-hole bond & -23.77 & 2.04863 & - \\
\hline $\mathbf{T B}+9$ & $\pi-\pi$ stacking & -10.09 & - & - \\
\hline $\mathbf{T B}+10$ & Hydrogen bond & -9.62 & 1.84169 & 161.41892 \\
\hline $\mathbf{T B}+11$ & Hydrogen bond & -11.35 & 1.93421 & 165.97918 \\
\hline $\mathrm{TB}+12$ & Hydrogen bond & -8.64 & 2.11109 & 164.76507 \\
\hline $\mathbf{T B}+13$ & Hydrogen bond & -10.23 & 2.10965 & 167.55641 \\
\hline $\mathrm{TB}+14$ & $\pi$-hole bond & -13.05 & - & - \\
\hline $\mathbf{T B}+15$ & $\pi$-hole bond & -12.66 & - & - \\
\hline $\mathrm{TB}+16$ & $\pi$-hole bond & -11.21 & - & - \\
\hline
\end{tabular}




\section{DFT calculations}

TB 1,3,5-Trimethoxybenzene

$\begin{array}{lrrr}\mathrm{C} & 0.55024552 & 1.28725294 & 0.00004612 \\ \mathrm{C} & -0.81904903 & 1.11219011 & 0.00000023 \\ \mathrm{C} & -1.39015398 & -0.16740989 & 0.00002604 \\ \mathrm{C} & -0.55370231 & -1.26559490 & 0.00013830 \\ \mathrm{C} & 0.83990359 & -1.12042269 & 0.00003566 \\ \mathrm{C} & 1.37300420 & 0.15298339 & 0.00006851 \\ \mathrm{H} & 1.02115782 & 2.25776550 & -0.00001784 \\ \mathrm{H} & -2.46602160 & -0.24511203 & 0.00002285 \\ \mathrm{H} & 1.44470285 & -2.01365640 & 0.00003065 \\ \mathrm{O} & -1.70985453 & 2.13399362 & -0.00010371 \\ \mathrm{O} & -0.99344477 & -2.54799774 & 0.00025646 \\ \mathrm{O} & 2.70328507 & 0.41378539 & 0.00000887 \\ \mathrm{C} & -1.20003422 & 3.44804833 & 0.00002201 \\ \mathrm{H} & -0.59612502 & 3.63719509 & -0.89156830 \\ \mathrm{H} & -2.06298021 & 4.10881563 & 0.00014133 \\ \mathrm{H} & -0.59603535 & 3.63697896 & 0.89159630 \\ \mathrm{C} & 3.58650155 & -0.68472341 & -0.00012973 \\ \mathrm{H} & 4.59027191 & -0.26780542 & -0.00010700 \\ \mathrm{H} & 3.44798202 & -1.30232433 & 0.89133052 \\ \mathrm{H} & 3.44792800 & -1.30212985 & -0.89171666 \\ \mathrm{C} & -2.38656505 & -2.76254321 & -0.00020913 \\ \mathrm{H} & -2.52837004 & -3.84007628 & 0.00035017 \\ \mathrm{H} & -2.85206816 & -2.33279889 & 0.89078039 \\ \mathrm{H} & -2.85122997 & -2.33378615 & -0.89212351\end{array}$




\section{1 (Iodine monobromide)}

$\begin{array}{lrrr}\mathrm{I} & 0.00000000 & 0.00000000 & 0.98094477 \\ \mathrm{Br} & 0.00000000 & 0.00000000 & -1.48543065\end{array}$


$\underline{2 \text { (Cyanogen bromide) }}$

$\mathrm{N}$

$\begin{array}{lll}0.00000000 & 0.00000000 & -1.13679193\end{array}$

$\mathrm{Br}$

$\begin{array}{lll}0.00000000 & 0.00000000 & -2.28436663\end{array}$

$\begin{array}{lll}0.00000000 & 0.00000000 & 0.65175195\end{array}$ 
$\underline{3 \text { (Selenium tetrabromide) }}$

$\begin{array}{lrrr}\mathrm{Se} & 0.00000000 & 0.00000000 & 0.53097988 \\ \mathrm{Br} & -0.00000000 & 2.52073113 & 0.65696364 \\ \mathrm{Br} & 1.79853706 & -0.00000000 & -0.91486816 \\ \mathrm{Br} & -1.79853706 & 0.00000000 & -0.91486816 \\ \mathrm{Br} & -0.00000000 & -2.52073113 & 0.65696364\end{array}$


4 (Phosphorus oxybromide)

$\begin{array}{lccc}\mathrm{P} & 0.00000000 & 0.00000000 & 0.64375529 \\ \mathrm{Br} & 0.00000000 & 1.99001718 & -0.25163870 \\ \mathrm{Br} & 1.72340543 & -0.99500859 & -0.25163870 \\ \mathrm{Br} & -1.72340543 & -0.99500859 & -0.25163870 \\ \mathrm{O} & 0.00000000 & 0.00000000 & 2.09571678\end{array}$


$\underline{5 \text { (Antimony trichloride) }}$

$\mathrm{Sb}$

$\mathrm{Cl}$

$\begin{array}{lll}0.00000000 & 0.00000000 & 0.58524020\end{array}$

$\mathrm{Cl}$

$\begin{array}{lll}0.00000000 & 2.02430067 & -0.58524020\end{array}$

$\mathrm{Cl}$

$\begin{array}{lll}1.75309580 & -1.01215033 & -0.58524020\end{array}$

$\begin{array}{lll}-1.75309580 & -1.01215033 & -0.58524020\end{array}$ 
$\underline{6 \text { (Trimethyl tin chloride) }}$

$\begin{array}{lrrr}\text { Sn } & 0.00000000 & 0.00000000 & 0.26479440 \\ \mathrm{Cl} & 0.00000000 & 0.00000000 & -2.11164810 \\ \mathrm{C} & 0.00000000 & 2.07108145 & 0.80948433 \\ \mathrm{H} & 0.00000000 & 2.18786725 & 1.89288773 \\ \mathrm{H} & -0.88494528 & 2.55670181 & 0.40148609 \\ \mathrm{H} & 0.88494528 & 2.55670181 & 0.40148609 \\ \mathrm{C} & 1.79360915 & -1.03554072 & 0.80948433 \\ \mathrm{H} & 1.77169608 & -2.04473601 & 0.40148609 \\ \mathrm{H} & 1.89474863 & -1.09393363 & 1.89288773 \\ \mathrm{H} & 2.65664137 & -0.51196581 & 0.40148609 \\ \mathrm{C} & -1.79360915 & -1.03554072 & 0.80948433 \\ \mathrm{H} & -1.89474863 & -1.09393363 & 1.89288773 \\ \mathrm{H} & -1.77169608 & -2.04473601 & 0.40148609 \\ \mathrm{H} & -2.65664137 & -0.51196581 & 0.40148609\end{array}$


$\underline{7 \text { (Tin tetrabromide) }}$

Sn

$\mathrm{Br}$

$\mathrm{Br}$

$\mathrm{Br}$

$\mathrm{Br}$

$\begin{array}{rrr}0.00000000 & 0.00000000 & 0.00000000 \\ -0.00000000 & 2.00673405 & 1.42017021 \\ 2.00673405 & -0.00000000 & -1.42017021 \\ -0.00000000 & -2.00673405 & 1.42017021 \\ -2.00673405 & 0.00000000 & -1.42017021\end{array}$


$\underline{8 \text { (Gallium trichloride) }}$

$\begin{array}{lrrr}\mathrm{Ga} & 0.00000000 & 0.00000000 & 0.00000000 \\ \mathrm{Cl} & 0.00000000 & 2.12441535 & 0.00000000 \\ \mathrm{Cl} & -1.83979766 & -1.06220768 & 0.00000000 \\ \mathrm{Cl} & 1.83979766 & -1.06220768 & 0.00000000\end{array}$


9 (E)-Methyl-butenoic acid

$\begin{array}{lrrr}\mathrm{C} & 1.32948820 & 0.20956346 & 0.00000000 \\ \mathrm{C} & 0.00000000 & 0.31788451 & 0.00000000 \\ \mathrm{H} & 1.77122997 & -0.77901933 & 0.00000000 \\ \mathrm{C} & 2.24106474 & 1.39622185 & 0.00000000 \\ \mathrm{H} & 2.05959802 & 2.02383807 & 0.87647107 \\ \mathrm{H} & 3.28809202 & 1.10262215 & 0.00000000 \\ \mathrm{H} & 2.05959802 & 2.02383807 & -0.87647107 \\ \mathrm{C} & -0.71320721 & 1.63809296 & 0.00000000 \\ \mathrm{H} & -0.44110598 & 2.22641637 & -0.87905303 \\ \mathrm{H} & -1.78978424 & 1.49038686 & 0.00000000 \\ \mathrm{H} & -0.44110598 & 2.22641637 & 0.87905303 \\ \mathrm{C} & -0.85193199 & -0.89802626 & 0.00000000 \\ \mathrm{O} & -2.05482032 & -0.88534999 & 0.00000000 \\ \mathrm{O} & -0.16026762 & -2.05620350 & 0.00000000 \\ \mathrm{H} & -0.81830072 & -2.76448971 & 0.00000000\end{array}$


$\underline{10 \text { (N-Nitrosodiphenylamine) }}$

$\begin{array}{lrrc}\mathrm{N} & -0.05087060 & 0.87996869 & -0.00846809 \\ \mathrm{C} & -1.30264971 & 0.20927749 & -0.04954666 \\ \mathrm{C} & -2.44271886 & 0.81341779 & 0.47372341 \\ \mathrm{C} & -1.38259872 & -1.05670056 & -0.62086523 \\ \mathrm{C} & -3.65824289 & 0.15234689 & 0.40255206 \\ \mathrm{H} & -2.36973207 & 1.79111970 & 0.92685381 \\ \mathrm{C} & -2.60296958 & -1.71238957 & -0.67104585 \\ \mathrm{H} & -0.49317793 & -1.52103764 & -1.02530130 \\ \mathrm{C} & -3.74608677 & -1.11162111 & -0.16483650 \\ \mathrm{H} & -4.54222051 & 0.62692205 & 0.80827512 \\ \mathrm{H} & -2.65824231 & -2.69711302 & -1.11662009 \\ \mathrm{C} & 1.18240597 & 0.15697911 & 0.04077499 \\ \mathrm{C} & 2.14317127 & 0.34583473 & -0.94267826 \\ \mathrm{C} & 1.39406008 & -0.74303899 & 1.07543074 \\ \mathrm{H} & 1.96482957 & 1.05751834 & -1.73688610 \\ \mathrm{C} & 2.57471748 & -1.46868321 & 1.12067507 \\ \mathrm{H} & 0.62899573 & -0.87582496 & 1.83010039 \\ \mathrm{H} & 2.73996467 & -2.17459434 & 1.92381774 \\ \mathrm{C} & 3.32482139 & -0.37679598 & -0.88575401 \\ \mathrm{C} & 3.54148603 & -1.28542571 & 0.14151820 \\ \mathrm{H} & 4.46392996 & -1.84985402 & 0.17910314 \\ \mathrm{H} & -4.69704631 & -1.62550912 & -0.20812071 \\ \mathrm{H} & 4.07795535 & -0.23063777 & -1.64879203 \\ \mathrm{~N} & -0.09357262 & 2.22434087 & 0.00220097 \\ \mathrm{O} & 0.96793402 & 2.77870483 & 0.07396901 \\ & & & \\ & & & \\ \mathrm{H} & & & \end{array}$


11 (Diphenylmethanol)

$\begin{array}{lrrr}\mathrm{C} & -0.00732192 & 1.02671582 & 0.83826375 \\ \mathrm{H} & 0.02477692 & 0.98494509 & 1.93472513 \\ \mathrm{O} & -0.09268834 & 2.37499051 & 0.41371068 \\ \mathrm{H} & 0.75651149 & 2.79490636 & 0.57909543 \\ \mathrm{C} & -1.25673594 & 0.30068452 & 0.38251416 \\ \mathrm{C} & -1.43480666 & -1.03096230 & 0.74860329 \\ \mathrm{C} & -2.22221058 & 0.92764112 & -0.39277944 \\ \mathrm{C} & -2.56299614 & -1.72637048 & 0.34802324 \\ \mathrm{H} & -0.67582990 & -1.52655817 & 1.34442715 \\ \mathrm{C} & -3.35363766 & 0.22747992 & -0.79757137 \\ \mathrm{H} & -2.08615760 & 1.96282901 & -0.67236264 \\ \mathrm{C} & -3.52801987 & -1.09690985 & -0.42974740 \\ \mathrm{H} & -2.69027951 & -2.76118049 & 0.63904508 \\ \mathrm{H} & -4.10202557 & 0.72452159 & -1.40176589 \\ \mathrm{H} & -4.41028160 & -1.63914213 & -0.74475405 \\ \mathrm{C} & 1.24584936 & 0.36149811 & 0.30594577 \\ \mathrm{C} & 2.13516600 & -0.27817150 & 1.15837983 \\ \mathrm{C} & 1.51089022 & 0.38782130 & -1.06163041 \\ \mathrm{C} & 3.27694231 & -0.89189329 & 0.65506703 \\ \mathrm{H} & 1.93520697 & -0.29532810 & 2.22407800 \\ \mathrm{C} & 2.65073839 & -0.21614724 & -1.56410392 \\ \mathrm{H} & 0.81093569 & 0.88431503 & -1.72375709 \\ \mathrm{C} & 3.53594075 & -0.86046995 & -0.70573739 \\ \mathrm{H} & 3.96409445 & -1.38823640 & 1.32833100 \\ \mathrm{H} & 2.85020628 & -0.19242128 & -2.62778582 \\ & 4.42555964 & -1.33407158 & -1.10032457 \\ & & & \\ \mathrm{H} & & & \\ \mathrm{H} & & \end{array}$


12 (Diphenylamine)

$\begin{array}{lrrr}\mathrm{N} & 0.00000327 & 1.06758394 & -0.00006218 \\ \mathrm{H} & 0.00000624 & 2.07335364 & -0.00002053 \\ \mathrm{C} & 1.25370081 & 0.46054617 & 0.02176177 \\ \mathrm{C} & 2.35501504 & 1.17672461 & -0.45391255 \\ \mathrm{C} & 1.45946663 & -0.81605298 & 0.54948247 \\ \mathrm{C} & 3.62537694 & 0.62949842 & -0.40788208 \\ \mathrm{H} & 2.20282524 & 2.16686757 & -0.86778973 \\ \mathrm{C} & 2.73388242 & -1.36014899 & 0.57484811 \\ \mathrm{H} & 0.62583758 & -1.36779964 & 0.96113509 \\ \mathrm{C} & 3.82510565 & -0.64837919 & 0.09696136 \\ \mathrm{H} & 4.46443838 & 1.20390249 & -0.77956533 \\ \mathrm{H} & 2.87385556 & -2.35037608 & 0.98997912 \\ \mathrm{H} & 4.81663863 & -1.07915830 & 0.12467926 \\ \mathrm{C} & -1.25369835 & 0.46055324 & -0.02181281 \\ \mathrm{C} & -2.35498528 & 1.17672752 & 0.45392886 \\ \mathrm{C} & -1.45949482 & -0.81603817 & -0.54954089 \\ \mathrm{C} & -3.62535126 & 0.62950442 & 0.40795693 \\ \mathrm{H} & -2.20277293 & 2.16686541 & 0.86781008 \\ \mathrm{C} & -2.73391216 & -1.36013194 & -0.57484674 \\ \mathrm{H} & -0.62588678 & -1.36777836 & -0.96124566 \\ \mathrm{C} & -3.82510893 & -0.64836545 & -0.09689317 \\ \mathrm{H} & -4.46439170 & 1.20390502 & 0.77969285 \\ \mathrm{H} & -2.87390895 & -2.35035323 & -0.98998364 \\ \mathrm{H} & -4.81664427 & -1.07914204 & -0.12456386\end{array}$


13 (N-Phenyl-1-naphthylamine)

\begin{tabular}{|c|c|c|c|}
\hline $\mathrm{C}$ & 4.27883443 & -1.18312471 & 0.28824337 \\
\hline $\mathrm{C}$ & 4.05051346 & 0.14932729 & 0.09252130 \\
\hline $\mathrm{C}$ & 2.73602421 & 0.65203226 & -0.06252396 \\
\hline $\mathrm{C}$ & 1.64648786 & -0.25595686 & -0.02816633 \\
\hline $\mathrm{C}$ & 1.91220472 & -1.62690660 & 0.20359042 \\
\hline $\mathrm{C}$ & 3.19389485 & -2.08011027 & 0.35593538 \\
\hline $\mathrm{H}$ & 3.33243277 & 2.71919709 & -0.24760469 \\
\hline $\mathrm{H}$ & 5.28939505 & -1.55234239 & 0.40562993 \\
\hline $\mathrm{H}$ & 4.87667458 & 0.84950223 & 0.05574451 \\
\hline $\mathrm{C}$ & 2.49276495 & 2.03589078 & -0.23457169 \\
\hline $\mathrm{C}$ & 0.31937303 & 0.24736619 & -0.21964938 \\
\hline $\mathrm{H}$ & 1.09057111 & -2.32434570 & 0.29829716 \\
\hline $\mathrm{H}$ & 3.37676764 & -3.13044514 & 0.54211579 \\
\hline $\mathrm{C}$ & 0.12423553 & 1.59704433 & -0.38613179 \\
\hline $\mathrm{C}$ & 1.21392738 & 2.48902922 & -0.37959419 \\
\hline $\mathrm{H}$ & -0.87437246 & 1.97676450 & -0.55222186 \\
\hline $\mathrm{H}$ & 1.02309348 & 3.54591421 & -0.51556724 \\
\hline $\mathrm{N}$ & -0.72937394 & -0.67677372 & -0.25898384 \\
\hline $\mathrm{H}$ & -0.52976536 & -1.52392116 & -0.76536159 \\
\hline $\mathrm{C}$ & -2.08713462 & -0.40417570 & -0.08953224 \\
\hline $\mathrm{C}$ & -3.02687774 & -1.13622863 & -0.81675544 \\
\hline $\mathrm{C}$ & -2.53832492 & 0.53113931 & 0.84447823 \\
\hline $\mathrm{C}$ & -4.38336263 & -0.93873775 & -0.61578582 \\
\hline $\mathrm{H}$ & -2.68430045 & -1.86224229 & -1.54531214 \\
\hline $\mathrm{C}$ & -3.89649670 & 0.73090016 & 1.02684916 \\
\hline $\mathrm{H}$ & -1.82089789 & 1.08322469 & 1.43639278 \\
\hline $\mathrm{C}$ & -4.82971079 & 0.00175812 & 0.30126773 \\
\hline $\mathrm{H}$ & -5.09440372 & -1.51945033 & -1.18949821 \\
\hline $\mathrm{H}$ & -4.22918812 & 1.45812344 & 1.75679123 \\
\hline $\mathrm{H}$ & -5.88850715 & 0.16195392 & 0.45243291 \\
\hline
\end{tabular}


14 (Octafluoronaphthalene)

$\begin{array}{lrrr}\text { C } & -2.41635713 & -0.70293305 & -0.00004071 \\ \text { C } & -1.23981785 & -1.39159338 & -0.00020825 \\ \text { C } & 0.00000514 & -0.71243507 & -0.00012888 \\ \text { C } & -0.00001779 & 0.71243147 & 0.00013678 \\ \text { C } & -1.23982529 & 1.39160107 & 0.00031190 \\ \text { C } & -2.41637288 & 0.70294441 & 0.00022340 \\ \text { C } & 1.23984509 & -1.39159433 & -0.00030922 \\ \text { C } & 1.23982824 & 1.39158234 & 0.00021310 \\ \text { C } & 2.41635935 & 0.70294591 & 0.00004090 \\ \text { C } & 2.41637903 & -0.70295736 & -0.00022560 \\ \text { F } & 1.28498047 & -2.71697860 & -0.00056080 \\ \text { F } & 3.57551238 & -1.33917622 & -0.00039350 \\ \text { F } & 3.57548881 & 1.33918762 & 0.00011428 \\ \text { F } & 1.28498301 & 2.71697393 & 0.00046419 \\ \text { F } & -1.28498371 & 2.71697502 & 0.00055995 \\ \text { F } & -3.57549653 & 1.33919126 & 0.00038877 \\ \text { F } & -3.57547984 & -1.33919581 & -0.00011870 \\ \text { F } & -1.28502185 & -2.71697185 & -0.00046314\end{array}$


$\underline{15}(3,4,5,6$-Tetrafluorophthalonitrile)

$\begin{array}{lrrr}\text { C } & -0.00000000 & 1.38194566 & -0.34805194 \\ \text { C } & -0.00000000 & 0.69160840 & -1.55225010 \\ \text { C } & -0.00000000 & -0.69160840 & -1.55225010 \\ \text { C } & -0.00000000 & -1.38194566 & -0.34805194 \\ \text { C } & 0.00000000 & -0.70254436 & 0.85867889 \\ \text { C } & 0.00000000 & 0.70254436 & 0.85867889 \\ \text { F } & -0.00000000 & 2.70043081 & -0.37545516 \\ \text { F } & -0.00000000 & 1.35032979 & -2.69240300 \\ \text { F } & -0.00000000 & -1.35032979 & -2.69240300 \\ \text { F } & -0.00000000 & -2.70043081 & -0.37545516 \\ \text { C } & 0.00000000 & -1.44673426 & 2.07951891 \\ \text { C } & 0.00000000 & 1.44673426 & 2.07951891 \\ \text { N } & 0.00000000 & -2.04861029 & 3.05476413 \\ \text { N } & 0.00000000 & 2.04861029 & 3.05476413\end{array}$


$\underline{\mathbf{1 6} \text { (1,4-Diiodotetrafluorobenzene) }}$

$\begin{array}{lrrc}\text { C } & -0.00000000 & 1.18971579 & 0.69242727 \\ \mathrm{C} & 0.00000000 & 1.18971579 & -0.69242727 \\ \mathrm{C} & 0.00000000 & 0.00000000 & -1.40196409 \\ \mathrm{C} & -0.00000000 & -1.18971579 & -0.69242727 \\ \mathrm{C} & -0.00000000 & -1.18971579 & 0.69242727 \\ \mathrm{C} & -0.00000000 & 0.00000000 & 1.40196409 \\ \mathrm{~F} & -0.00000000 & 2.35436288 & 1.32661824 \\ \mathrm{~F} & -0.00000000 & -2.35436288 & -1.32661824 \\ \mathrm{~F} & -0.00000000 & -2.35436288 & 1.32661824 \\ \mathrm{~F} & 0.00000000 & 2.35436288 & -1.32661824 \\ \mathrm{I} & 0.00000000 & 0.00000000 & 3.46915362 \\ \mathrm{I} & 0.00000000 & 0.00000000 & -3.46915362\end{array}$




\section{REFERENCES}

1. Garau, C.; Frontera, A.; Quinonero, D.; Ballester, P.; Costa, A.; Deya, P. M., A topological analysis of the electron density in anion-pi interactions. ChemPhysChem 2003, 4, 1344-1348.

2. Francisco, M.; van den Bruinhorst, A.; Kroon, M. C., Low-Transition-Temperature Mixtures (LTTMs): A New Generation of Designer Solvents. Angew. Chem. Int. Ed. 2013, 52, 3074-3085.

3. Wojnarowska, Z.; Smolka, W.; Zotova, J.; Knapik-Kowalczuk, J.; Sherif, A.; Tajber, L.; Paluch, M., The effect of electrostatic interactions on the formation of pharmaceutical eutectics. Phys. Chem. Chem. Phys. 2018, 20, 27361-27367.

4. Chen, Z.; Greaves, T. L.; Warr, G. G.; Atkin, R., Mixing cations with different alkyl chain lengths markedly depresses the melting point in deep eutectic solvents formed from alkylammonium bromide salts and urea. Chem. Commun. 2017, 53, 2375-2377. 